\title{
DPF is a cell-density sensing factor, with cell-autonomous and non-autonomous functions during Dictyostelium growth and development
}

\author{
Netra Pal Meena ${ }^{1 \dagger}$, Pundrik Jaiswal ${ }^{1 \dagger}$, Fu-Sheng Chang ${ }^{1}$, Joseph Brzostowski ${ }^{1,2}$ and Alan R. Kimmel ${ }^{1 *}$
}

\begin{abstract}
Background: Cellular functions can be regulated by cell-cell interactions that are influenced by extra-cellular, density-dependent signaling factors. Dictyostelium grow as individual cells in nutrient-rich sources, but, as nutrients become depleted, they initiate a multi-cell developmental program that is dependent upon a cell-density threshold. We hypothesized that novel secreted proteins may serve as density-sensing factors to promote multi-cell developmental fate decisions at a specific cell-density threshold, and use Dictyostelium in the identification of such a factor.

Results: We show that multi-cell developmental aggregation in Dictyostelium is lost upon minimal (2-fold) reduction in local cell density. Remarkably, developmental aggregation response at non-permissive cell densities is rescued by addition of conditioned media from high-density, developmentally competent cells. Using rescued aggregation of low-density cells as an assay, we purified a single, 150-kDa extra-cellular protein with density aggregation activity. MS/MS peptide sequence analysis identified the gene sequence, and cells that overexpress the full-length protein accumulate higher levels of a development promoting factor (DPF) activity than parental cells, allowing cells to aggregate at lower cell densities; cells deficient for this DPF gene lack density-dependent developmental aggregation activity and require higher cell density for cell aggregation compared to WT. Density aggregation activity co-purifies with tagged versions of DPF and tag-affinity-purified DPF possesses density aggregation activity. In mixed development with WT, cells that overexpress DPF preferentially localize at centers for multi-cell aggregation and define cell-fate choice during cytodifferentiation. Finally, we show that DPF is synthesized as a larger precursor, single-pass transmembrane protein, with the p150 fragment released by proteolytic cleavage and ectodomain shedding. The TM/cytoplasmic domain of DPF possesses cell-autonomous activity for cell-substratum adhesion and for cellular growth.

Conclusions: We have purified a novel secreted protein, DPF, that acts as a density-sensing factor for development and functions to define local collective thresholds for Dictyostelium development and to facilitate cell-cell communication and multi-cell formation. Regions of high DPF expression are enriched at centers for cell-cell signalresponse, multi-cell formation, and cell-fate determination. Additionally, DPF has separate cell-autonomous functions for regulation of cellular adhesion and growth.
\end{abstract}

Keywords: Signaling, Chemotaxis, Protein purification, MS/MS peptide sequencing, Ecto-domain shedding

\footnotetext{
* Correspondence: alank@helix.nih.gov

${ }^{+}$Netra Pal Meena and Pundrik Jaiswal contributed equally and should be considered as co-first authors.

'Laboratory of Cellular and Developmental Biology, National Institute of

Diabetes and Digestive and Kidney Diseases, The National Institutes of

Health, Bethesda, MD 20892, USA

Full list of author information is available at the end of the article
}

(c) The Author(s). 2019 Open Access This article is distributed under the terms of the Creative Commons Attribution 4.0 International License (http://creativecommons.org/licenses/by/4.0/), which permits unrestricted use, distribution, and reproduction in any medium, provided you give appropriate credit to the original author(s) and the source, provide a link to the Creative Commons license, and indicate if changes were made. The Creative Commons Public Domain Dedication waiver (http://creativecommons.org/publicdomain/zero/1.0/) applies to the data made available in this article, unless otherwise stated. 


\section{Background}

Cell-density sensing is broadly associated with response to signaling molecules that accumulate in the extracellular milieu in proportion to cellular mass. While perhaps often described as quorum sensing in the context of bacterial sociality and virulence [1], it is recognized that secreted factors in both prokaryotes and eukaryotes are sensed and function most effectively at threshold concentrations that directly reflect local cell density [2]. As example, where it is critical to accumulate sufficient cell mass to ensure productive organ development, cell proliferation may proceed at the expense of developmental processes [3-5]. Thereby, the secretion and accumulation of dependent concentrations of specific molecules can be a read-out for effective cell density. Other secreted, regulatory factors modulate action at differential signal strengths, thus directing distinct distal/proximal events from centers of the dispersing signal origin [6-8]. Changing concentrations relative to distance thereby provide an effective parallel for monitoring the local collective cellular environmental.

Many extracellular signaling molecules have been described, and their functions quite varied, underscoring importance to understand the nature of factors that affect a fundamental switch in developmental cell fate. Dictyostelium are social amoeboid eukaryotes with growth and developmental characteristics that make them highly suited to explore cell density-dependent accumulation of such extracellular signaling molecules.

Dictyostelium grow in the wild as individual cells, engulfing bacteria as a food source [9-11]. If bacteria are fully cleared within an area of an expanding population of Dictyostelium, the cells become starved for nutrients and enter a phase for multi-cell aggregate formation to maximize survival by differentiation, development, movement, and finally dispersal to regions with new, abundant nutrient sources. Development and survival are compromised at cell numbers below an optimized target, and the size-area of aggregation territories, as reflective of participating cell numbers, is highly regulated [12-16].

Within a nutrient depleted area, Dictyostelium cells establish signaling centers at stochastic intervals for production and secretion of the chemoattractant cAMP in temporal waves [10, 17]. Proximal cells respond by movement inward toward these centers of wave production and by relay outward of cAMP to recruit additional more distal cells. Secreted waves of cAMP also synchronize cAMP timing in all cells within the defining territory, to ensure a single dominating cAMP signaling center to collect cells for aggregate formation [18, 19]. Mutants or pharmaceuticals that enhance or suppress cAMP signaling, respectively, increase or decrease numbers of signaling centers and reciprocally territory size [12, 20-23].
Dictyostelium has been an ideal system for identification of extracellular proteins that regulate proliferation and growth or development and fate choice, and molecules, in addition to cAMP, can be secreted by Dictyostelium to allow cells to assess their near cell density to promote aggregation for optimal development and survival [12-16]. Chalones are secreted proteins that limit rates of cell proliferation, to control cell numbers in developing tissues. The AprA-CfaD complex in Dictyostelium exhibits chalone-like negative feedback control that limits cell proliferation [24, 25], whereas other secreted factors appear to completely block cell division [26]. PSF, the pre-starvation factor, accumulates in the media of cells entering stationary growth, but prior to the initiation of development $[27,28]$. PSF primes cells for developmental response by inducing low expression of genes that will be required for starvation-induced cAMP response and control of early development. CF (Countin Factor) proteins $\mathrm{CtnA}, \mathrm{CtnB}$, etc., inversely control group size of developing Dictyostelium [29-31], whereas CMF, conditioned media factor, will promote Dictyostelium cytodifferentiation under conditions of extreme cell dilution and in the absence of cell-cell contact [32].

We were interested to identify secreted molecules that regulate cell density-dependent developmental processes. We show that Dictyostelium at low cell-density conditions are unable to form multi-cell developmental aggregates upon nutrient withdrawal; however, addition of media from developmentally competent cells allowed aggregation at these non-permissive cell densities. We identified a density aggregation activity as a $150-\mathrm{kDa}$ protein (p150) that is secreted by ectodomain shedding of a single-pass transmembrane precursor. Gain-of-function studies show that the density-dependent aggregation activity affinity purifies with p150 and that cells overexpressing this p150 development promoting factor (DPF) aggregate at non-permissive densities, below that required by parental cells. In contrast, cells lacking the gene for $D P F$ are unable to aggregate at normal cell densities. We additionally show, using mixed development studies, that cells overexpressing DPF preferentially localize at centers for aggregate formation for cAMP signaling and cell-fate determination, relative to WT. Finally, DPF is synthesized as a precursor, single-pass transmembrane protein, which is processed by proteolytic cleavage and ectodomain shedding. The active $150-\mathrm{kDa} \mathrm{N}$-terminus is released, while the TM/cytoplasmic domain remains cellanchored and possesses cell-autonomous functions for cellsubstratum adhesion and for cellular growth.

\section{Results}

Dictyostelium secrete a factor that modulates cell-densitydependent, developmental aggregation

When deprived of nutrients, Dictyostelium initiate a developmental program leading to multi-cell aggregation 
[9-11]. Cells plated on a solid substrate in non-nutrient media secrete oscillating, $\mathrm{nM}$ waves of cAMP, which is the developmental chemoattractant that defines centers for multi-cell recruitment and aggregate formation [10, $12,17,20,22]$. However, the response processes that collectively mobilize cells at aggregation centers are highly dependent on cell density [12-16, 21, 23]; a twofold reduction in cell density can be sufficient to strongly suppress aggregation (see Fig. 1; Additional file 1: Figure $\mathrm{S} 1 \mathrm{~A}, \mathrm{~B}, \mathrm{C})$. Certainly, several groups have described various secreted proteins in Dictyostelium that show increased accumulation in parallel to cell growth and serve as effective density sensing factors [12]. We were interested to identify additional secreted factors that regulate Dictyostelium development in a cell-density-dependent manner. We approached this, using aggregation as a read-out for developmental progression and by developing starved cells under-buffer in microtitre plastic dish wells, where added factors would not be diluted by absorption into supporting matrices, such as agar or filter pads.

WT Dictyostelium were washed from growth media and allowed to starve overnight in developmental buffer (DB), at $1-2 \times 10^{7}$ cells $/ \mathrm{ml}$ in shaking culture. The conditioned media from the starved cells were collected and a cell-free, $>30 \mathrm{kDa}$ fraction prepared by filter centrifugation; we chose a size fraction cut-off to remove effects of secreted cAMP and other small molecules. Growthphase WT cells were then washed and resuspended in either naïve $\mathrm{DB}$ or conditioned starvation DB media, and plated under-buffer in microtitre dishes at varying cell densities. Here, cell aggregation was visually monitored after $24 \mathrm{~h}$.

As seen previously [13-16], Dictyostelium have a very sharp cell-density threshold cut-off for aggregation/non- aggregation, regardless of media treatment used (Fig. 1; Additional file 1: Figure S1A,B). However, use of conditioned DB media for plated development of WT cells allowed aggregation at a 4-fold lower cell density than cells incubated in naïve media (Fig. 1; Additional file 1: Figure S1B). Additionally, we examined effect of conditioned media on cells lacking the signaling inhibitory, heterotrimeric $\mathrm{G}$ protein $\mathrm{G} \alpha 9$ (Additional file 1: Figure S1C [21]). Go9-null cells aggregate at a lower density than WT [21] and show greater sensitivity for aggregation with conditioned WT media, to a $>16$-fold celldensity dilution effect (Additional file 1: Figure S1C). These data suggest that starved cells secrete and accumulate a large sized activity that alters cell-density sensitivity for development.

\section{Purification of a cell-density aggregation factor}

The extreme sensitivity of Dictyostelium developmental aggregation to limiting cell density defined an ideal assay for purification of density sensing factors. The concentrated $>30-\mathrm{kDa}$ conditioned $\mathrm{DB}$ media preparation was first subject to Mono $\mathrm{Q}$ anion exchange chromatography, and fractions were tested on WT cells at subaggregation densities $\left(<20 \times 10^{3}\right.$ cells $\left./ \mathrm{cm}^{2}\right)$. A densitydependent developmental aggregation activity bound strongly to Mono Q columns eluting at $250 \mathrm{mM}$ sodium chloride (Fig. 2a; Additional file 2: Figure S2). The Mono $\mathrm{Q}$ eluted activity also bound strongly to phenyl sepharose (for hydrophobic interaction), fractionating in a step gradient at $750 \mathrm{mM}$ ammonium sulfate (Fig. 2a; Additional file 2: Figure S2). Many secreted proteins in Dictyostelium are modified with glycosyl moieties [33], and the aggregation activity bound wheat germ agglutinin lectin and could be eluted with glucosamine. Fewer than 20 proteins were detected in this eluate by SDS gel

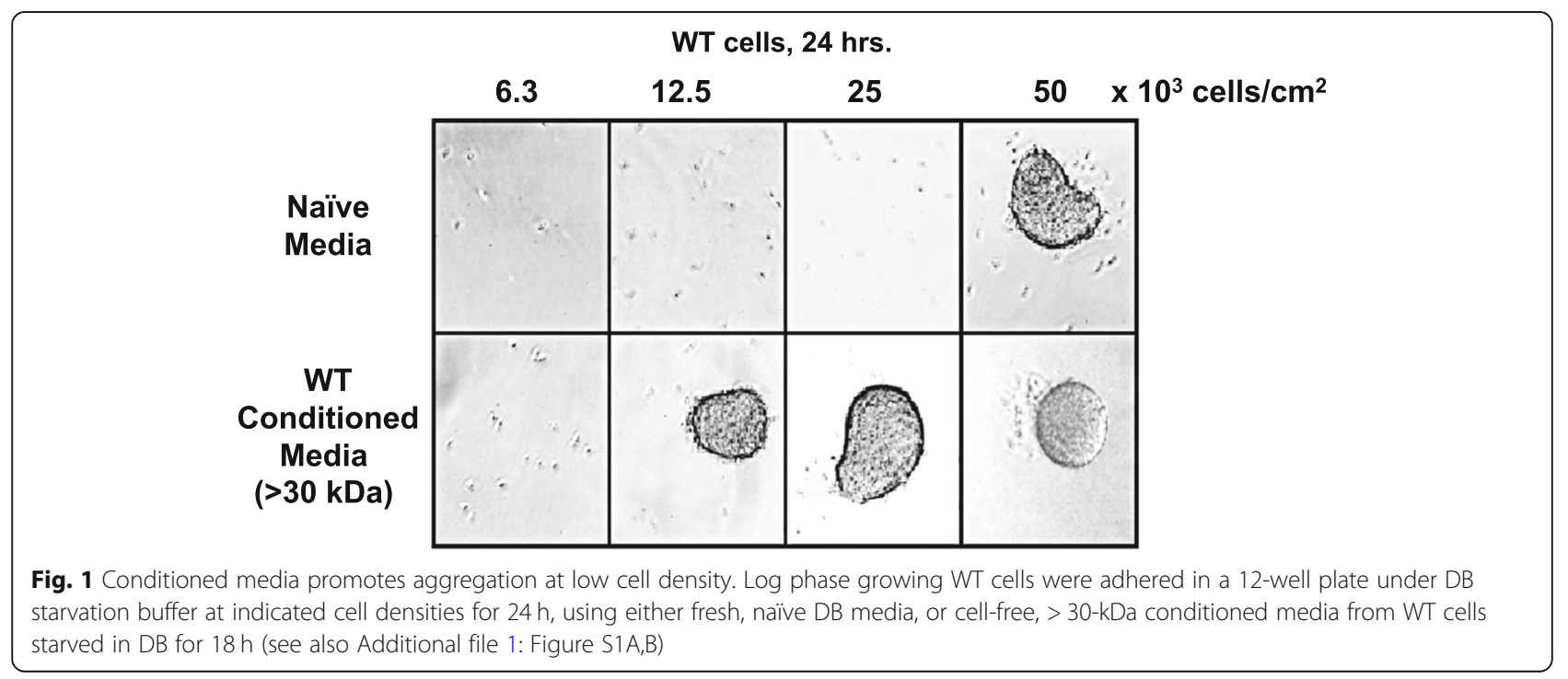


electrophoresis (Fig. 2a). Finally, the activity was sizefractioned on Sepharose 12, where maximal activity was restricted to several fractions (Fig. 2a), at a MW of $250 \mathrm{kDa}$.

When the proteins in the Sepharose 12 activity fractions were separated by SDS gel electrophoresis, 6 definitive protein bands were identified in sufficient quantities for MS/MS peptide sequence analyses. Each band (see Fig. 2a; Additional file 3: Figure S3) gave peptides that matched precisely with annotated proteins in Dictyostelium [34, 35]. Several well-characterized proteins were among these, including cysteine proteases, $\alpha$ mannosidase, and PDE1 (PdsA), the secreted phosphodiesterase which degrades extracellular cAMP (Additional file 3: Figure S3A). Two additional novel proteins of $67 \mathrm{kDa}(\mathrm{p} 67)$ and $150 \mathrm{kDa}(\mathrm{p} 150)$ were identified. p67 is similar to FAD-dependent oxidoreductases (Additional file 3: Figure S3B); p150 has a small EGF-type domain, but is otherwise unique (Additional file 3: Figure S3C). Clearly, none of the proteins had molecular weights in the $250-\mathrm{kDa}$ range, suggesting that several multi-protein complexes might be present in the Sepharose 12 fraction, with at least one with cell-density aggregation activity.

The cysteine proteases, $\alpha$-mannosidase, and PDE1 do not have properties that are consistent with density sensitive aggregation. In fact, high doses of PDE1 decrease extracellular cAMP levels and so inhibit, rather than promote, low-density cell aggregation. We show directly that cells lacking PDE1 accumulate a density aggregation activity in our assay (Additional file 4: Figure S4), as do cells lacking secreted CMF (a developmental factor) and secreted CtnA (a Countin Factor complex protein), known secreted density factors $[29,36]$. We suggest that a secreted density developmental aggregation activity is likely associated with either p150 or p67.

PDE1 is found in several multi-protein complexes in Dictyostelium, and often in non-specific associations [37]. We speculated that density-dependent aggregation activity from WT cells might fractionate in a large nonspecific protein agglomerate involving PDE1 and, thus, fractionate differently in extracts from $P D E 1$-null cells, which retains the cell density-dependent aggregation activity (Additional file 4: Figure S4). The most dramatic fractionation difference we observe using PDE1-null cell media is an elution shift of the density-dependent aggregation activity on Sepharose 12 from an apparent MW of $\sim 250 \mathrm{kDa}$ in WT media to a smaller MW fraction of $\sim 150 \mathrm{kDa}$ from PDE1-null cell media (Fig. 2b, c). When these fractions are examined by SDS gel electrophoresis, p150 and p67 are the most prominent proteins. MS/MS peptide sequencing confirmed identity to previous sequencing. The low relative abundance of p67 in activity fraction 22 suggests that p150 might more likely possess density-dependent aggregation activity. We term p150 as a developmental promoting factor (DPF) and sought to support this conclusion through loss-of-function and gain-of-function studies.

We studied p67 and p150 in loss-of-function studies by gene disruption (see the "Methods" section). Media from $p 67$-null cells retain the density aggregation activity (see Additional file 4: Figure S4), suggesting that p67, a FAD-dependent oxidoreductase, is not involved in density-dependent development. However, conditioned media from cells with disruption in the p150 coding sequence ( $D P F^{-}$cells) were unable to promote low density (e.g., $25 \times 10^{3}$ cells $/ \mathrm{cm}^{2}$ ) aggregation of WT cells (Fig. 3). Furthermore, the DPF-null, p150-deficient cells showed enhanced sensitivity to cell-density dilution for aggregation. Although aggregation of DPF-null, p150-deficient cells is inefficient at cell densities (e.g., $50 \times 10^{3}$ cells/ $\mathrm{cm}^{2}$ ) standard for WT cells, it can be restored using conditioned media from WT, but not from DPF-null cells (Fig. 3); still, the DPF-deficient cells seem less responsive to conditioned media than are WT cells (see below, Fig. 9d). Nonetheless, these data suggest that secreted p150 (i.e., DPF) is a previously uncharacterized protein that promotes early developmental events in Dictyostelium.

\section{DPF has secreted activity for promoting cell-density developmental aggregation}

The annotated full-length protein for DPF is 1483 amino acids with a predicted $\mathrm{N}$-terminal signal peptide and a C-terminal transmembrane domain (Fig. 4a; Additional file 3: S3C) that could anchor the protein in the plasma membrane. With processing of the signal peptide, a p160 fragment of DPF would be inserted into the plasma membrane as a single-pass protein. DPF mRNA is expressed during growth but is induced to high levels early in development (Fig. 4b), with maximal expression levels at $1-2 \mathrm{~h}$ after starvation on filters [38, 39]. Fusion of the WT DPF $\left(\mathrm{DPF}^{\mathrm{OE}}\right)$ or N-terminal FLAG-tagged DPF (N-FLAG ${ }^{\mathrm{OE}}$ ) versions (see Fig. 4a) to an actin promoter overexpressed DPF mRNA > 10×, compared to WT cells (Fig. 4b). We also examined the timedependent accumulation of secreted DPF after growing cells were transferred into fresh growth media or fresh DB starvation buffer at similar cell densities (Fig. 4c). The antibody used to detect DPF is not sufficiently sensitive to reproducibly quantify relative levels of WT protein (see below, Fig. 6c), but overexpressed DPF accumulates in extracellular media to $\sim 10 \times$ greater level than for WT and at similar rates under growing or starved conditions.

Next, we showed that after shifting growing cells into DB starvation buffer, N-FLAG ${ }^{\mathrm{OE}}$ cells (WT Dictyostelium cells, which overexpress N-FLAG DPF) accumulate 
A.

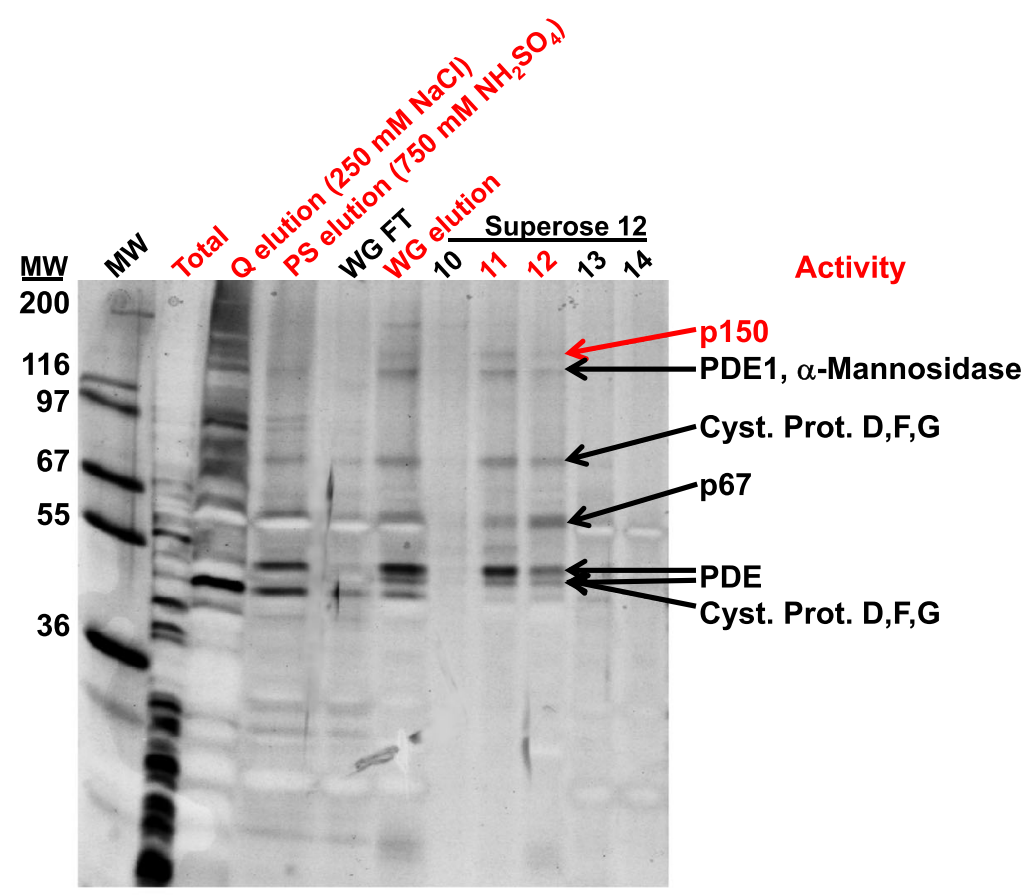

B.

\section{PDE1 -}

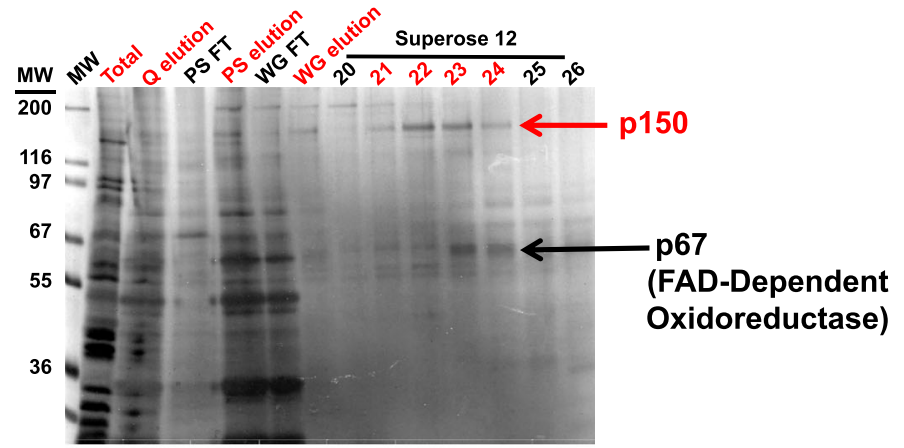

c.
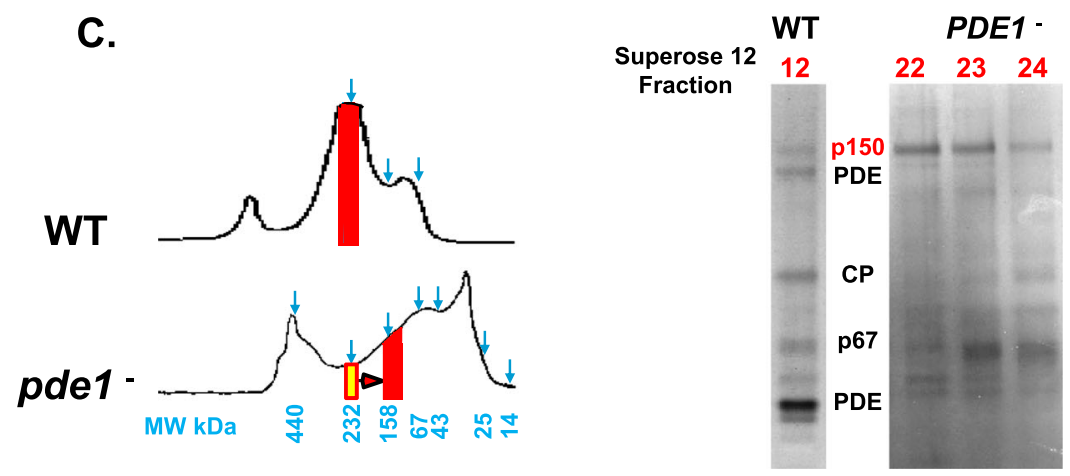

\section{Activity}

Fig. 2 (See legend on next page.) 
(See figure on previous page.)

Fig. 2 Purification of the density aggregation activity. a The cell-free, $>30-k D a$ conditioned media from WT cells were fractionated on mono Q, phenyl sepharose (PS), wheat germ agglutinin (WG), and Superose 12 columns. Fractions were assayed for density-dependent aggregation activity on WT cells at low cell density $\left(<20 \times 10^{3}\right.$ cells $\left./ \mathrm{cm}^{2}\right)$. Selected bound or flow through (FT) fractions separated by SDS gel electrophoresis are shown. Gels were stained with silver and protein bands indicated from Superose 12 fractions (e.g., 11 and 12) were used for peptide sequencing. Proteins matching each band are indicated (see Additional file 3: Figure S3). b The procedure followed Fig. 2a, but using conditioned DB from PDE1-null cells. Superose 12 fractions 22, 23, and 24 were used for MS/MS peptide sequencing. c Comparison of Superose 12 fractionations of conditioned DB from WT or PDE1-nulls cells, with protein profiles, relative MW positions, and activity position shift indicated. Relative fractionation differences for the proteins in Fig. 2a are also shown

a density-dependent aggregation activity several hours more quickly and to a higher level than do parental WT cells (Fig. 4d). These data suggest strongly that DPF is involved with a secreted cell-density developmental aggregation activity. Comparing cellular responses to media conditioned for only $5 \mathrm{~h}$ by WT or DPF ${ }^{\mathrm{OE}}$ cells provides a finer level of experimental control. For some experiments below, DPF effects were more specifically defined by comparing responses to short-term $(\sim 5 \mathrm{~h})$ accumulated conditioned media from WT or $\mathrm{DPF}^{\mathrm{OE}}$ cells, which would, respectively, possess minimal or higher levels of DPF. Thus, $5 \mathrm{~h}$ accumulated media from $\mathrm{DPF}^{\mathrm{OE}}$ cells will induce aggregation of low-density WT cells within $8 \mathrm{~h}$, whereas comparable WT media is completely ineffective (Fig. 4e).

Following, we fractionated media from N-FLAG-DPF overexpressing cells on Mono $\mathrm{Q}$ and tracked purification of the FLAG motif, by immunoblot assay, and in parallel,

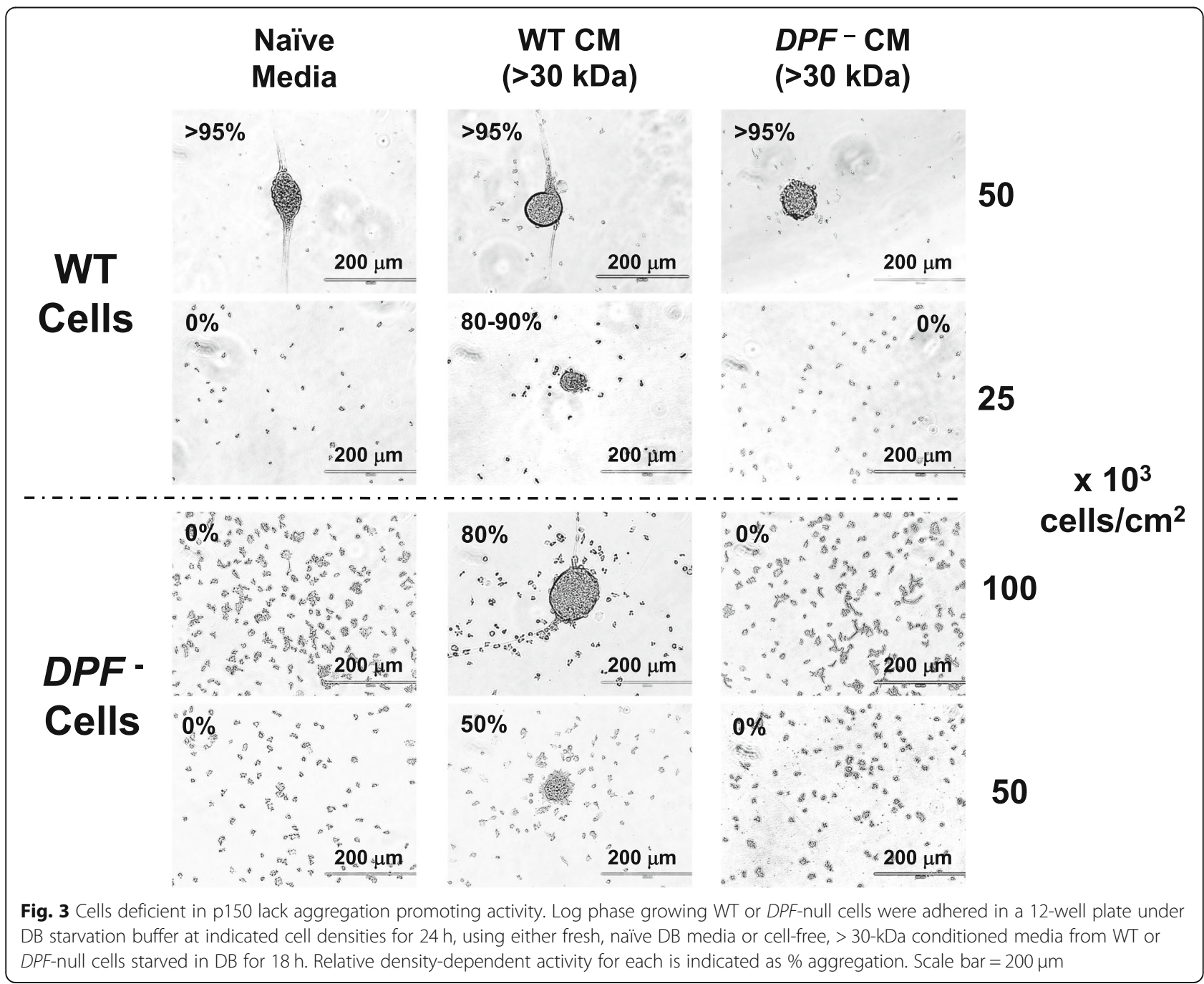


A.

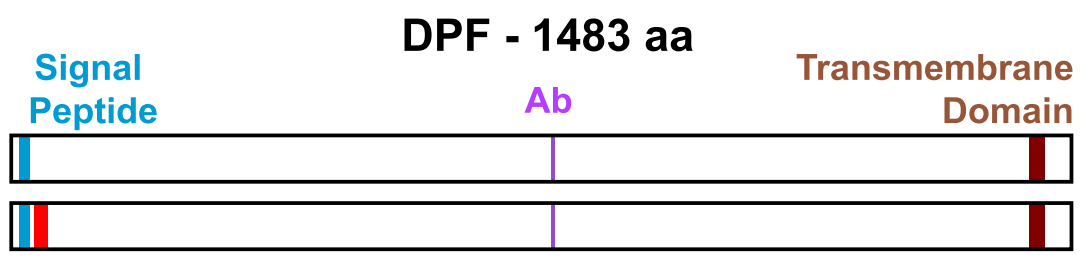

N-FLAG

B. WT Development

Growth

$\begin{array}{lllllllll}0 & 5 & 10 & 15 & 20 & 25 & \mathrm{hrs} & \text { WT } & \text { DPFOE N-FLAGOE }\end{array}$

DPF mRNA

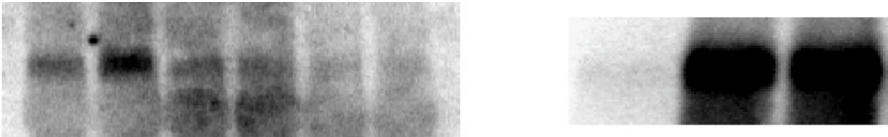

C.

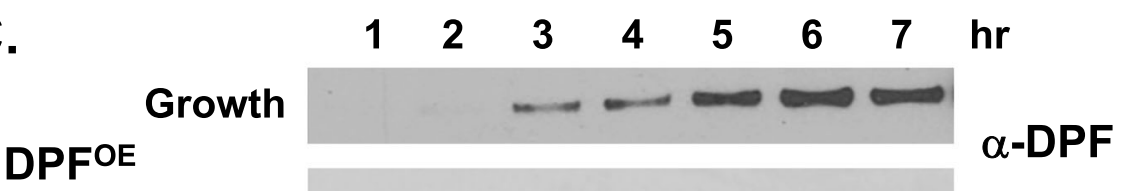

D.

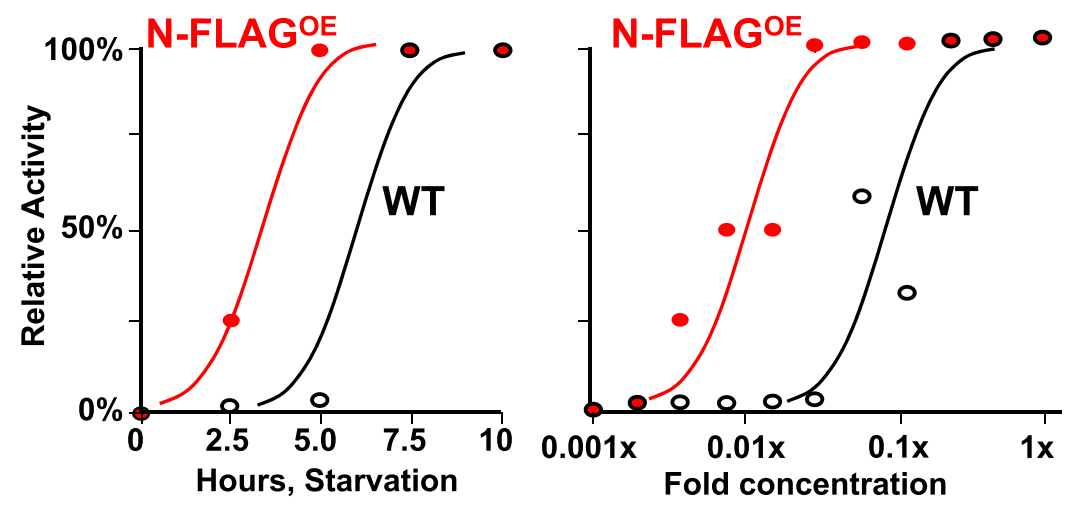

E.

WT Cells

Naïve Media

(DB)

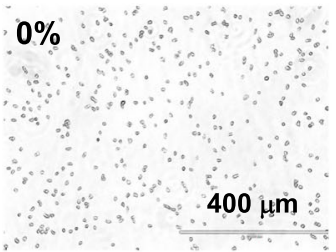

WT 5hr Starvation CM (>30 kDa)

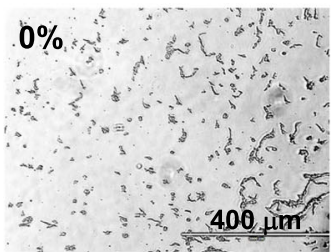

DPFOE 5hr Starvation CM (>30 kDa)

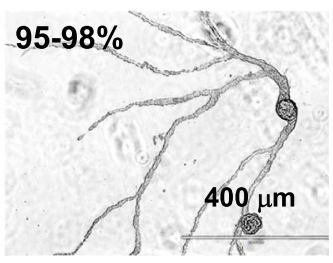

$25 \times 10^{3} \mathrm{cells} / \mathrm{cm}^{2} ; 8 \mathrm{hr}$ aggregation 
(See figure on previous page.)

Fig. 4 p150 protein structure, as termed DPF, and expression patterns. a Predicted structure of protein p150 (DPF). Full-length DPF has an Nterminal signal peptide and C-terminal transmembrane domain. An antibody was to a specific peptide (Additional file 3: Figure S3C). The relative positions these features are positioned along the 1483 amino acid backbone. The N-FLAG DPF expression construct was created with a FLAG peptide sequence inserted in-frame, $3^{\prime}$ to the signal peptide. $\mathbf{b}$ Left panel_-developmental expression of DPF mRNA at indicated times for WT cells, using RNA-blot hybridization. Right panel—relative DPF mRNA levels in growing WT cells, WT cells expressing full-length DPF (DPF ${ }^{\mathrm{OE}}$ ), or WT cells expressing full-length FLAG-tagged DPF (N-FLAG ${ }^{\mathrm{OE}}$ ), using RNA-blot hybridization. $\mathbf{c}$ Log-phase growing WT cells overexpressing DPF (DPF ${ }^{\mathrm{OE}}$ ) were transferred into fresh growth media or fresh DB starvation buffer at similar cell densities and supernatant fractions taken and immunoblotted to a-DPF (see Fig. 4a). $\mathbf{d}$ Left panel—growing WT or WT cells expressing full-length FLAG-tagged DPF (N-FLAG ${ }^{\mathrm{OE}}$ ) were transferred into fresh DB. Cell-free media were taken at times indicated and tested for relative density-dependent aggregation activity, using WT cells at $20 \times 10^{3}$ cells $/ \mathrm{cm}^{2}$. Right panel — media collected at $7.5 \mathrm{~h}$ from both WT or N-FLAG ${ }^{\mathrm{OE}}$ cells were diluted into fresh DB, as indicated, and tested for relative density-dependent aggregation activity, using WT cells at $20 \times 10^{3} \mathrm{cells} / \mathrm{cm}^{2}$. Starting medium (1X) is 10 -fold diluted, from a centricon concentrate of conditioned supernatant. e Log-phase growing WT cells were plated under DB buffer at $25 \times 10^{3} \mathrm{cells} / \mathrm{cm}^{2} \mathrm{for} 8 \mathrm{~h}$, using either fresh, naïve DB media, or cell-free, $>30-k D a$ conditioned media from WT or DPF ${ }^{\mathrm{OE}}$ cells starved in DB for $5 \mathrm{~h}$ (see Fig. $\left.4 \mathrm{~d}, \mathrm{e}\right)$. Relative density-dependent activity is indicated as \% aggregation. Scale $=400 \mu \mathrm{m}$

tested for density-dependent aggregation activity. We show that the N-FLAG-DPF protein eluted in MONO Q fractions 16-20 (Fig. 5a), in precise co-elution with density aggregation activity (Fig. 5b). We then prepared MONO Q fractions from WT cells overexpressing WTDPF $\left(\mathrm{DPF}^{\mathrm{OE}}\right)$ and N-FLAG DPF (N-FLAG $\left.{ }^{\mathrm{OE}}\right)$, and affinity-purified the fractions with $\alpha$-FLAG-agarose (Fig. 5c). The fractionated media from both cell lines had similar starting density aggregation activity, but only the N-FLAG-variant of DPF showed enrichment to $>50 \times$ with $\alpha$-FLAG-agarose (Fig. 5c). We conclude that the secreted DPF protein promotes developmental aggregation at limiting cell densities.

\section{Processed DPF is secreted by ectodomain shedding of a single-pass transmembrane protein}

The structure of DPF (see Fig. 4a) places it as a singlepass transmembrane protein with a long, glycosylated $150-\mathrm{kDa}$ extracellular domain that is eventually secreted into the media. To understand the mechanism for secretion, we expressed N- and C-terminal FLAG-tagged variants of DPF and examined their cellular localizations (Fig. 6a). The N-terminal FLAG is seen associated with a $150-\mathrm{kDa}$ protein in media preparations, but in a larger, $160 \mathrm{kDa}, \mathrm{MW}$ form in cellular membranes (Fig. 6b). The C-terminal FLAG is in two size variants in membranes, at $160 \mathrm{kDa}$ and $10 \mathrm{kDa}$ (Fig. 6a). The p10 variant is > $10 \times$ more abundant than the $160-\mathrm{kDa}$ form. We suggest that the $160-\mathrm{kDa}$ protein is a near, full-length transmembrane protein that has been signal peptide processed and glycosylated, and can be marked with both $\mathrm{N}$ and C-terminal FLAG epitopes. Extracellular protease cleavage then releases a glycosylated p150 protein, which possesses DPF activity. Following ectodomain shedding, the residual $10-\mathrm{kDa}$ protein remains membrane bound.

To examine processing differently, we expressed DPF with a C-terminal GFP tag (Fig. 6c). We see a strong p150 signal in media compared to WT cells using the $\alpha$ DPF (Fig. 6d). A weak signal may correspond to the WT band (Fig. 6d). In membranes, we see C-terminal GFP fusion band at the expected MW of $\sim 35 \mathrm{kDa}$. Most of the GFP staining is associated with the cell periphery (Fig. 6e).

\section{Gain-of-function activities in WT cells expressing high levels of DPF}

Next, we compared the behavior of WT cells and DPF ${ }^{\mathrm{OE}}$ cells during aggregation. As expected for a density aggregation factor, $\mathrm{DPF}^{\mathrm{OE}}$ cells are able to form aggregates at lower cell plating densities than for WT (Fig. 7a). Possibly, the DPF ${ }^{\mathrm{OE}}$ cells become developmentally primed during growth in advance of WT and, thus, are able to initiate development at lower cell densities. To examine this, we looked for precocious expression of Discoidin 1 and CAR1 in $\mathrm{DPF}^{\mathrm{OE}}$ cells, which are sensitive to prestarvation induction as cell densities rise during growth $[27,28]$. First, we show a large relative expression increase in Discoidin 1 protein levels with only a 3-fold increase in growth cell density. Nonetheless, expression levels of Discoidin 1 are largely similar comparing WT and $\mathrm{DPF}^{\mathrm{OE}}$ cells (Fig. 7b). We see only limited expression of CAR1 at growing cell densities to $5 \times 10^{6}$ cells/ $\mathrm{ml}$ in both WT and DPF ${ }^{\mathrm{OE}}$ cells, and no expression level differences between the two cell lines upon starvation (Fig. 7b). Thus, the data indicate that at starvation, $\mathrm{DPF}^{\mathrm{OE}}$ and WT cells are at developmentally similar states.

We also studied chemotaxis of WT and DPF ${ }^{\mathrm{OE}}$ cells to cAMP in the IncuCyte system [40, 41]. Cells were washed from media to remove exposure to endogenous DPF and then followed for chemotaxis for $4 \mathrm{~h}$; during this time frame, significant levels of secreted DPF accumulate for $\mathrm{DPF}^{\mathrm{OE}}$ cells, but not for WT cells (see Fig. $4 d, e)$. Nonetheless, there were no statistically significant differences in migration during the course of the experiment between in WT and DPF ${ }^{\mathrm{OE}}$ cells (Fig. 7c). Neither did we see a chemotaxis rate change for $\mathrm{DPF}^{\mathrm{OE}}$ cells during the time course of the evaluation, indicating that 
A.

$\alpha-F L A G$

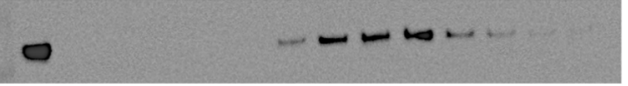

B.

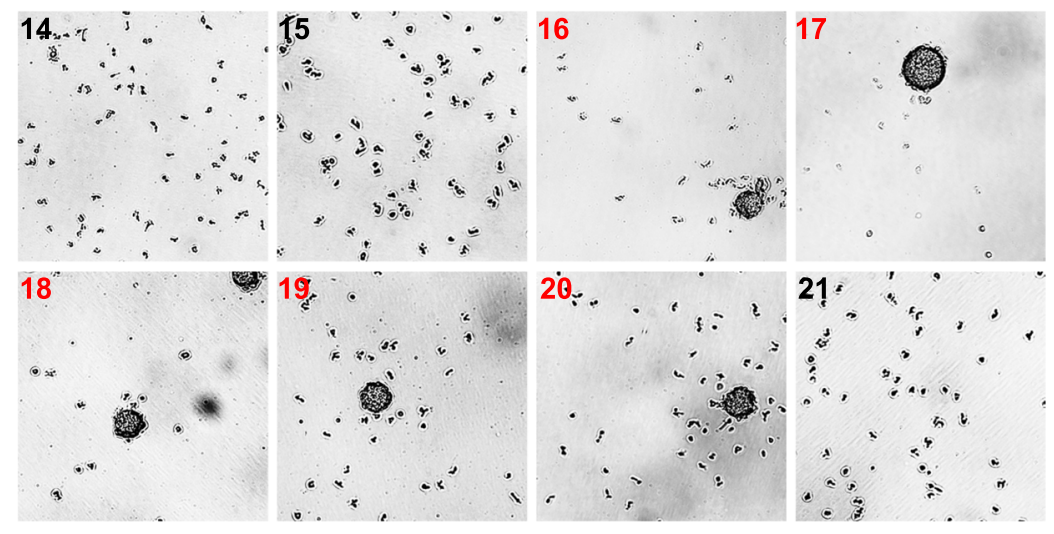

C.

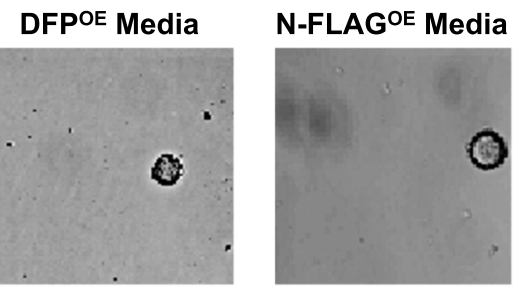

FLAG Affinity
Purification

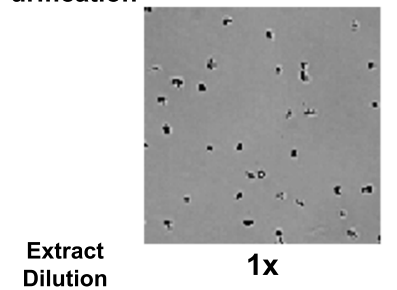

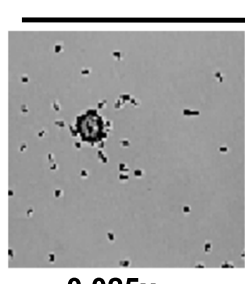

$0.025 x$

N-FLAGOE Media

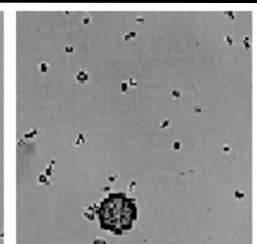

$0.25 x$

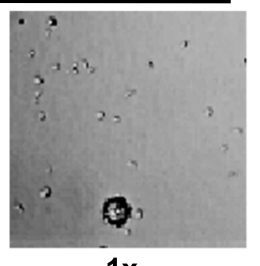

$1 \mathrm{x}$

Fig. 5 FLAG-p150 co-purifies with density aggregation activity. a/b Conditioned media from N-FLAG ${ }^{\mathrm{OE}}$ cells was fractionated on mono Q and eluate fractions assayed by immunoblot for FLAG protein (a) and for density-dependent aggregation activity (b) using WT cells at $20 \times 10^{3}$ cells/ $\mathrm{cm}^{2}$. c Upper panels-Mono Q fractionated media from DPF ${ }^{\mathrm{OE}}$ or $\mathrm{N}-\mathrm{FLAG}^{\mathrm{OE}}$ cells were assayed for density-dependent aggregation activity using WT cells at $20 \times 10^{3}$ cells $/ \mathrm{cm}^{2}$. Lower panels - media were affinity purified with a-FLAG and re-assayed at varying dilutions for density-dependent aggregation activity using WT cells at $20 \times 10^{3}$ cells $/ \mathrm{cm}^{2}$

accumulation of secreted DPF did not alter chemotactic sensitivity.

\section{Cells that overexpress DPF preferentially localize to aggregation centers and regulate prespore/spore patterns}

As might be expected, WT and $\mathrm{DPF}^{\mathrm{OE}}$ cells developed under high cell-density conditions $\left(>300 \times 10^{3}\right.$ cells/ $\mathrm{cm}^{2}$ ) would both accumulate DPF at developmentally sufficient levels and, thus, exhibit similar patterns for developmental aggregation, in timing, territory area, and size of aggregates (Fig. 8a). However, when cells were developed in mixed cultures at a 9:1 ratio of WT to $\mathrm{DPF}^{\mathrm{OE}}$, the $\mathrm{DPF}^{\mathrm{OE}}$ cells preferentially localize at centers for aggregate formation (Fig. 8b; Additional file 8: Movie S1), suggesting that high levels of DPF facilitate cell-cell communication to enable developmental signalresponse. Following aggregation, Dictyostelium 


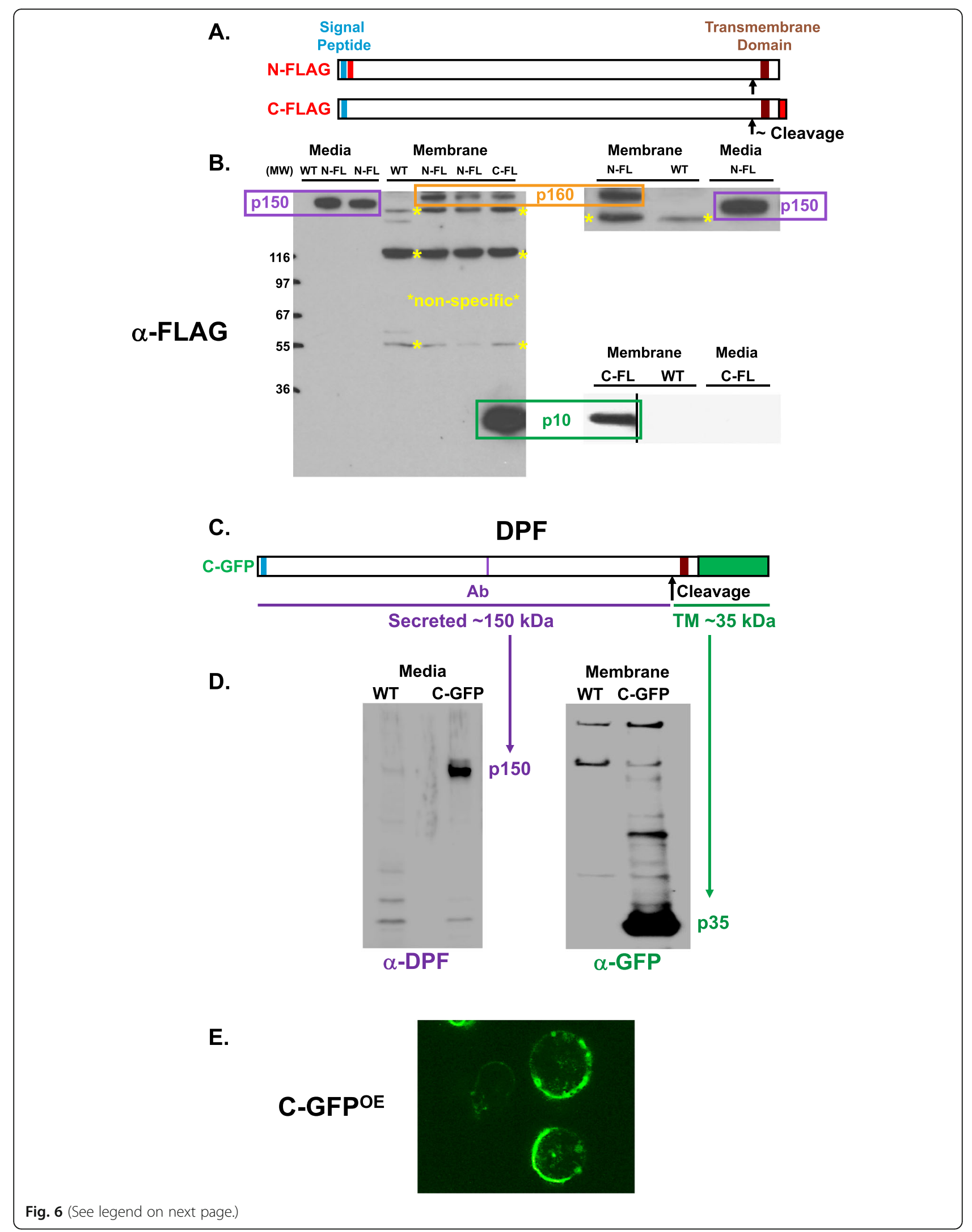




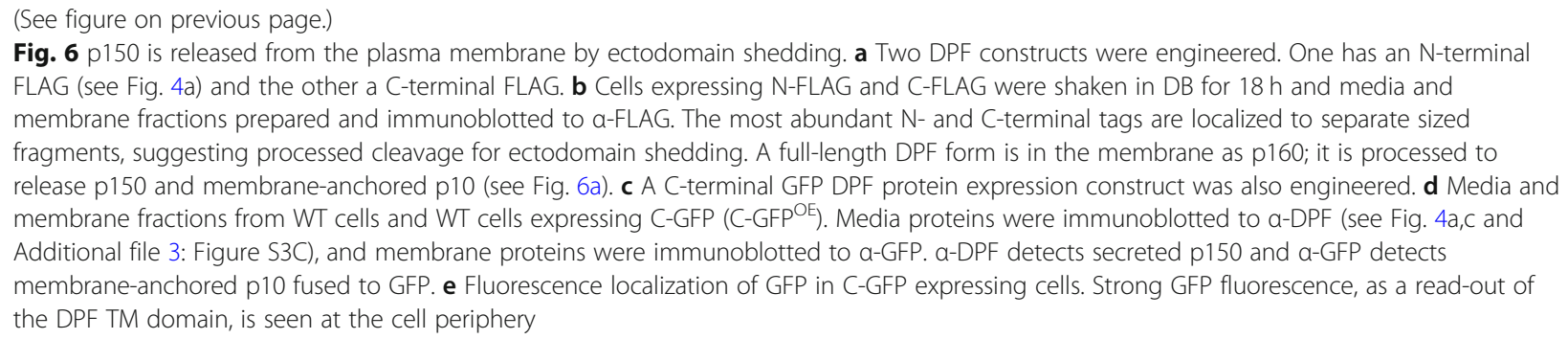

cytodifferentiate into two major precursor cell types, prespore and prestalk cells, which become spatially segregated, along an anterior (prestalk) and posterior (prespore) axis [42] of the developing pseudoplasmodia. Previous work $[21,43]$ had shown that cells which establish signaling centers for aggregation are preferentially fated to prespore cytodifferentiation. We show that $\mathrm{DPF}^{\mathrm{OE}}$ cells are not only locally enriched at centers for signaling, they also preferentially accumulate in prespore regions of the developing pseudoplasmodia and in spores during terminal differentiation (Fig. 8c), compared to WT and various controls (Additional file 5: Figure S5).

\section{Cell-autonomous functions for DPF}

Where WT cells are able to aggregate at densities of 50 $100 \times 10^{3}$ cells $/ \mathrm{cm}^{2}$ (see Figs. 1,3 , and 7a; Additional file 1: Figure S1), cells deficient in $D P F$ require densities > $200 \times 10^{3}$ cells $/ \mathrm{cm}^{2}$ for aggregation under buffer (Figs. 3 and 9a), supporting the role of DPF in densitydependent development. We also confirm a role for DPF in density sensing during standard developmental processes, where WT cells will aggregate at $4 \times$ lower cell density than will DPF-null cells on agar surfaces (Additional file 6: Figure S6A). Although WT and DPF-null cells both aggregate at $200 \times 10^{3}$ cells $/ \mathrm{cm}^{2}$ by $8 \mathrm{~h}$ (Additional file 6: Figure S6A), WT cells initiate the process several hours earlier (Additional file 6: Figure S6B); likewise, where $\mathrm{WT}$ and $\mathrm{DPF}^{\mathrm{OE}}$ cells aggregate at $50 \times 10^{3}$ cells $/ \mathrm{cm}^{2}$ (Fig. $7 \mathrm{a}$ ), DPF ${ }^{\mathrm{OE}}$ cells initiate the process earlier (Additional file 6: Figure S6C). Nonetheless, at the high cell density, aggregated $D P F$-null cells can proceed through terminal stages of differentiation (Additional file 6: Figure S6D). Furthermore, re-expression of full-length DPF in $D P F$-null $\left(D P F^{-\mathrm{OE}}\right)$ cells promotes aggregation at 3-4× lower cell densities (Fig. 9b). While conditioned media containing DPF is able to restore lower density aggregation of $D P F$-deficient cells (Fig. 3), it may not be as effective on DPF-null cells compared to WT. This may suggest that the TM/cytoplasmic domain of DPF may have a cell-autonomous function.

To better discern the role for membrane-bound DPF, apart from a secreted DPF form, we looked more clearly at development, using induced CAR1 expression as an essential marker read-out for early multi-cell development. CAR1 expression was monitored in DPF-null cells and DPF rescued $D P F$-null $\left(D P F^{\mathrm{OE}}\right)$ cells, under conditions restrictive $\left(100 \times 10^{3}\right.$ cells $\left./ \mathrm{cm}^{2}\right)$ or permissive $\left(400 \times 10^{3} \mathrm{cells} / \mathrm{cm}^{2}\right)$ to $D P F$-null aggregation. WT controls were monitored in parallel. For WT cells, CAR1 is similarly expressed irrespective of DPF expression levels at both cell-density conditions (Fig. 9c). However, results with DPF-nulls are quite distinct, although not unexpected. CAR1 is very poorly expressed under density conditions that are non-permissive for DPF-null aggregation $\left(100 \times 10^{3}\right.$ cells $\left./ \mathrm{cm}^{2}\right)$; however, re-expression of DPF in $D P F$-null $\left(D P F^{-\mathrm{OE}}\right)$ cells rescues CAR1 expression to WT levels (Fig. 9c). CAR1 expression is easily detected (the 2 resolved bands reflect known phosphorylation variants), under aggregation permissive conditions $\left(400 \times 10^{3}\right.$ cells $\left./ \mathrm{cm}^{2}\right)$ for DPF-null cells, although at reduced levels relative to parental cells; full expression is restored in $D P F$-null by re-expression of DPF (i.e., $D P F^{-\mathrm{OE}}$ cells).

Next, we examined the effects of conditioned media with or without secreted DPF, on CAR1 expression at a density $\left(100 \times 10^{3}\right.$ cells $\left./ \mathrm{cm}^{2}\right)$ permissive to WT cell aggregation but not to $D P F$-null cell aggregation. For aggregated WT cells, CAR1 expression is similar regardless of development in naïve $\mathrm{DB}$, or in 5 -h conditioned media from WT cells, $D P F$-null cells, or $\mathrm{DPF}^{\mathrm{OE}}$ cells (Fig. 9d); here only media from $\mathrm{DPF}^{\mathrm{OE}}$ cells contains significant levels of secreted DPF (see Fig. 4d, e). In contrast, CAR1 expression is relatively low in DPF-null cells developed in naïve $\mathrm{DB}$, in 5-h conditioned media from $D P F$-null cells, or in 5-h conditioned media from WT cells with limited levels of DPF (see Fig. 4d, e). Significant CAR1 induction is observed with 5-h conditioned media from $\mathrm{DPF}^{\mathrm{OE}}$ cells, but to levels below those of WT. By comparing data using full-length DPF overexpression or response to secreted DPF alone (Fig. 9d), we suggest that although cellular response to secreted DPF promotes aggregation and CAR1 expression, the TM/cytoplasmic domain of DPF, either as a full-length protein or as a truncated remnant following ectodomain shedding, may have cell-autonomous functions (see Fig. 11).

Indeed, we observe that $D P F$-null cells are more loosely attached to matrix surfaces than WT cells, 
A.

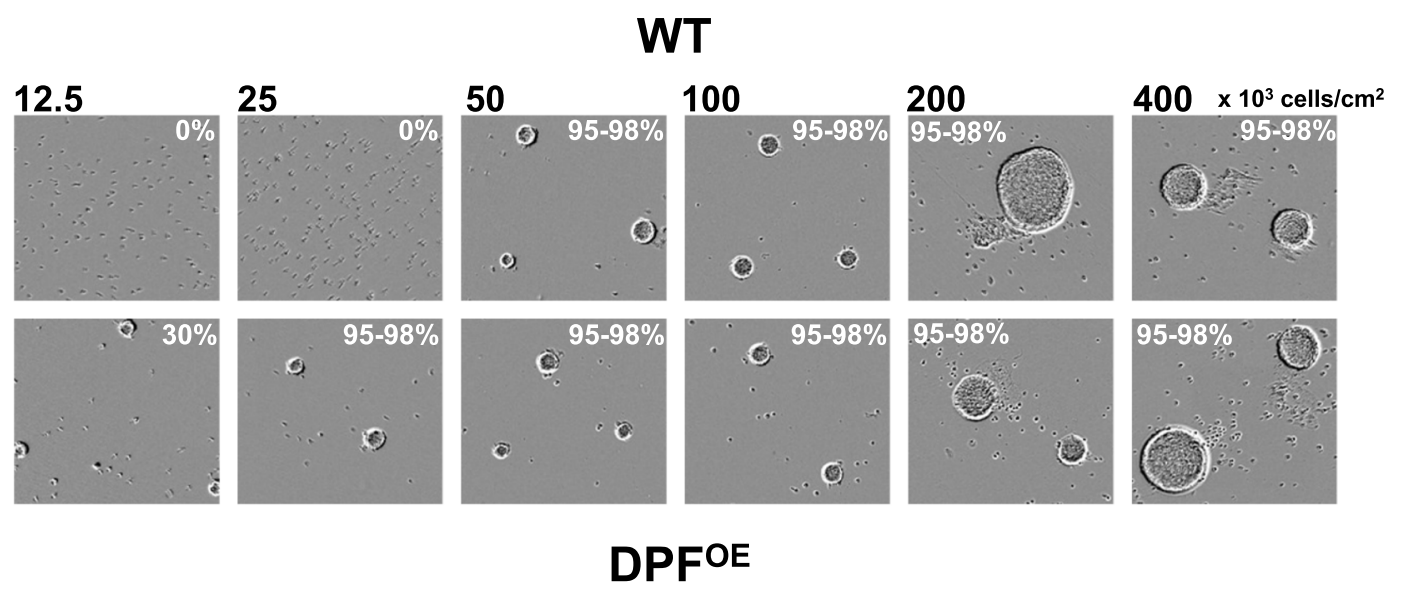

B.

$$
\left.\begin{array}{llllll}
\frac{2}{2} & \text { WT } & & \multicolumn{2}{c}{\text { DPFOE }} \\
\hline 0.5 & 1.0 & 3.0 & 0.5 & 1.0 & 3.0
\end{array} \text { [Growth }\left(\times 10^{6} \text { cells } / \mathrm{ml}\right)\right]
$$

Discoidin 1

Actin

\section{Actin}
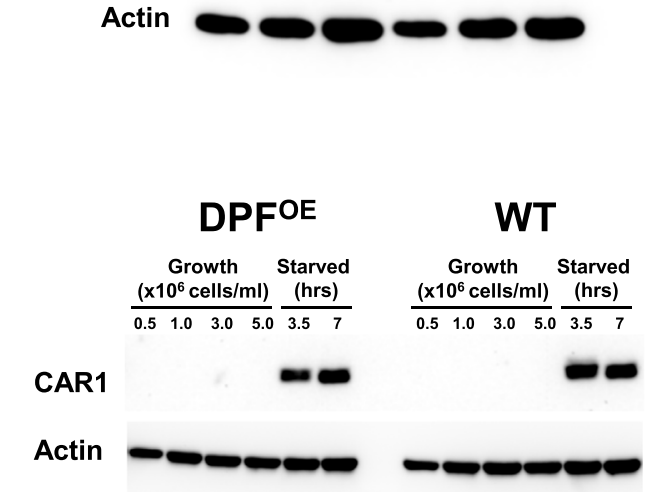

c.

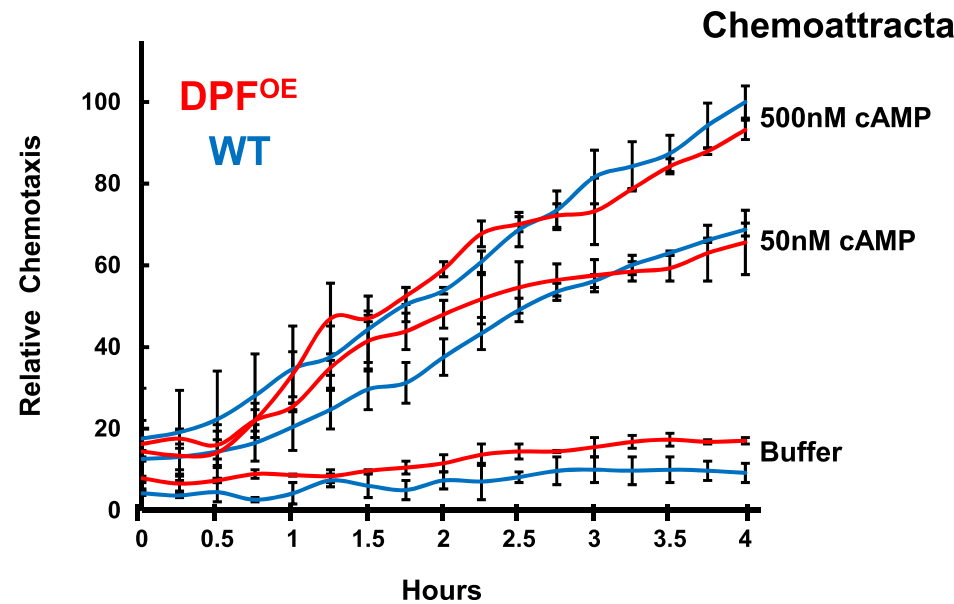

Fig. 7 (See legend on next page.) 
(See figure on previous page.)

Fig. 7 Gain-of-function studies of WT cells expressing high levels of DPF. a Log phase growing WT or DPF ${ }^{\mathrm{OE}}$ cells were plated under-buffer at indicated cell densities for $24 \mathrm{~h}$ using fresh, naïve DB media. Relative aggregation efficiencies are indicated. $\mathbf{b}$ WT and DPF ${ }^{\mathrm{OE}}, \mathrm{DPF}^{\mathrm{OE}}$ cells were grown to various cell densities in growth media and then identically starved as indicated. Cell lysates were prepared from cells at indicated times and immunoblotted to a-Discoidin 1, a-CAR1, and a-actin. c Time-course quantification of WT or DPF ${ }^{\mathrm{OE}}$ cell migration to various doses of cAMP. Relative chemotaxis is normalized to WT cells at $500 \mathrm{nM}$ cAMP at $4 \mathrm{~h}$. Standard deviations are shown based upon three replicates

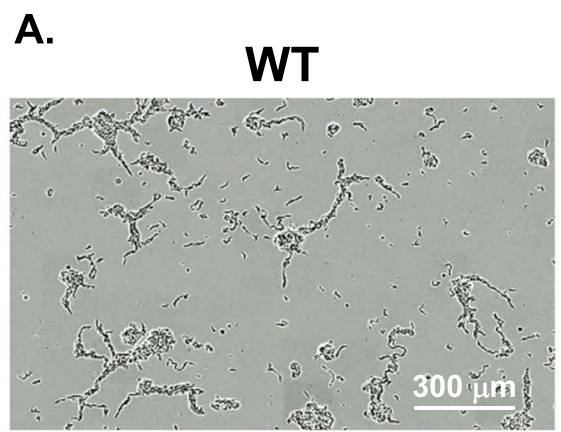

\section{$5.10 \mathrm{hr}$}

\section{C-GFPOE}

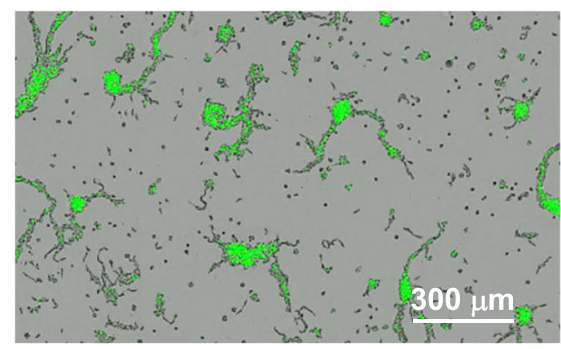

$5.00 \mathrm{hr}$
B.

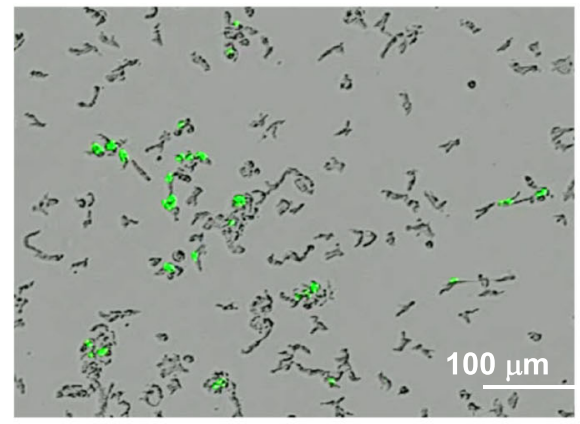

$90 \%$ WT: $10 \%$ C-GFPOE

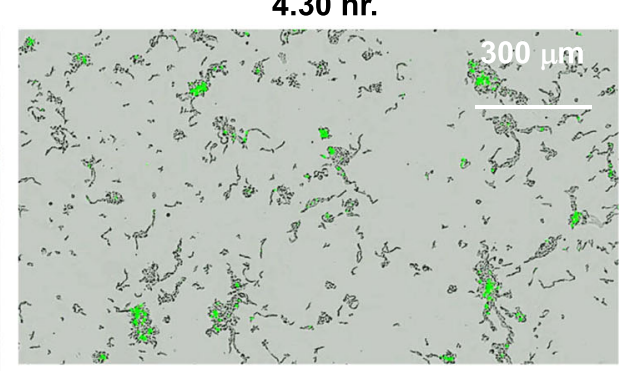

c.

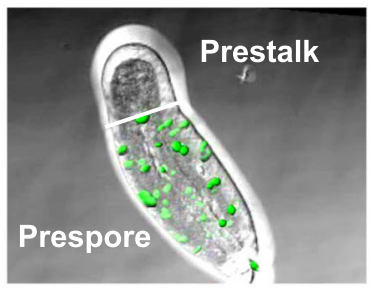

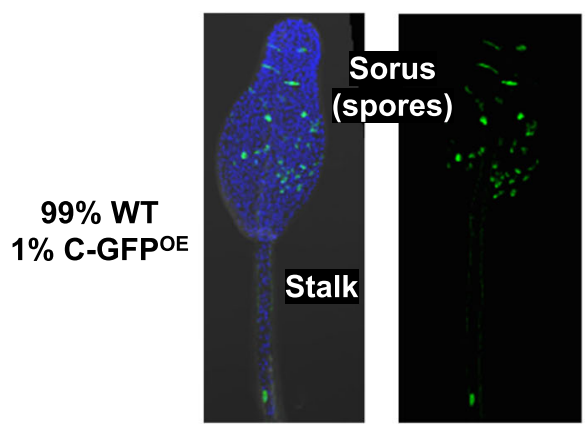

Fig. 8 Cells that overexpress DPF regulate prespore/spore patterning. a WT or C-GFPEE cells were identically plated on DB agar at a density of $400 \times 10^{3} \mathrm{cell} / \mathrm{s} / \mathrm{cm}^{2}$ for development and followed over time. Shown are similar time frame images including both DIC and GFP fluorescence. $\mathbf{b} \mathrm{A}$ 9:1 mixed population of WT or C-GFPOE cells were plated for development and followed over time. Shown are two time frame images including both DIC and GFP fluorescence (see Additional file 8: Movie S1). c A 99:1 mixed population of WT or C-GFPOE cells were plated for development and developed to the slug stage (left) or to terminal differentiation (right). Shown are confocal images including both DIC and GFP fluorescence, with prespore/prestalk and spore/stalk regions indicated 


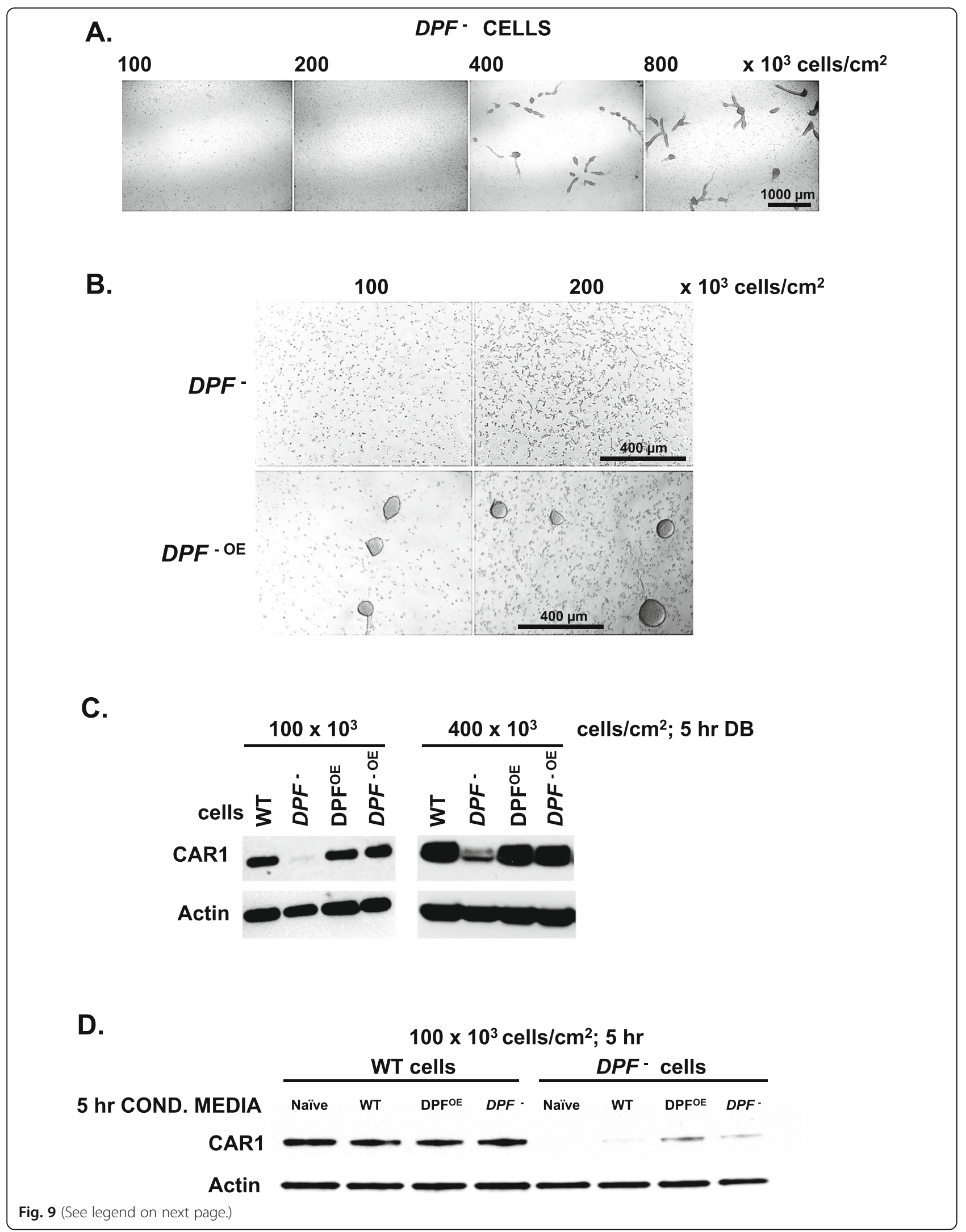


(See figure on previous page.)

Fig. 9 Cell-autonomous and non-autonomous functions of DPF in development. a Log phase growing DPF cells were adhered in a 12-well plate under fresh, naïve DB starvation buffer at indicated cell densities for $24 \mathrm{~h}$. $\mathbf{b}$ Log phase growing DPF or DPF ${ }^{-E}$ Dictyostelium were plated under fresh, naïve DB starvation buffer at indicated cell densities for $24 \mathrm{~h} . \mathbf{c} W T, D P F$, DPF ${ }^{\mathrm{OE}}$, and DPF ${ }^{\mathrm{OE}}$ cells were adhered in fresh, naive DB media at a density of $100 \times 10^{3}$ or $400 \times 10^{3}$ cells $/ \mathrm{cm}^{2}$ and developed for $5 \mathrm{~h}$. Cell lysates were prepared and immunoblotted to a-CAR1 and a-actin. $\mathbf{d}$ WT and DPF cells were adhered at a density of $100 \times 10^{3}$ cells $/ \mathrm{cm}^{2}$ and developed for $5 \mathrm{~h}$ using fresh, naïve DB media, or $>30-\mathrm{kDa}$ conditioned media from WT, DPF ${ }^{\mathrm{OE}}$, or DPF cells following starvation in DB for $5 \mathrm{~h}$. Cell lysates were prepared and immunoblotted to a-CAR1 and a-actin

perhaps partly explaining the different developmental effects of WT and DPF-null cells. We, therefore, quantified adherence to matrix surfaces using WT and DPFnull cells plated under naïve $\mathrm{DB}$ and under DB media conditioned for $5 \mathrm{~h}$ during starvation of $\mathrm{DPF}^{\mathrm{OE}}$ cells. Plates with attached cells were shaken at a constant speed and detached cells quantified over time. DPF-null cells were clearly less adherent than WT, with no statistically significant effect of secreted DPF (Fig. 10a).

We also observed that DPF-null cells grew more slowly than did WT cells, with $\sim 25 \%$ less volume on a collective cell basis (Additional file 7: Figure S7).
Although growth rate and volume of DPF-nulls can be restored to WT properties by re-expression of fulllength DPF (Additional file 7: Figure S7), DPF-null cells continue to grow more poorly than WT in fresh growth medium supplemented with conditioned growth media from WT cells that contain DPF (Fig. 10b). We conclude that DPF has a cell-autonomous function for adhesion and growth.

\section{Discussion}

We have identified DPF, a protein that is secreted during the early stages of Dictyostelium development and

A.
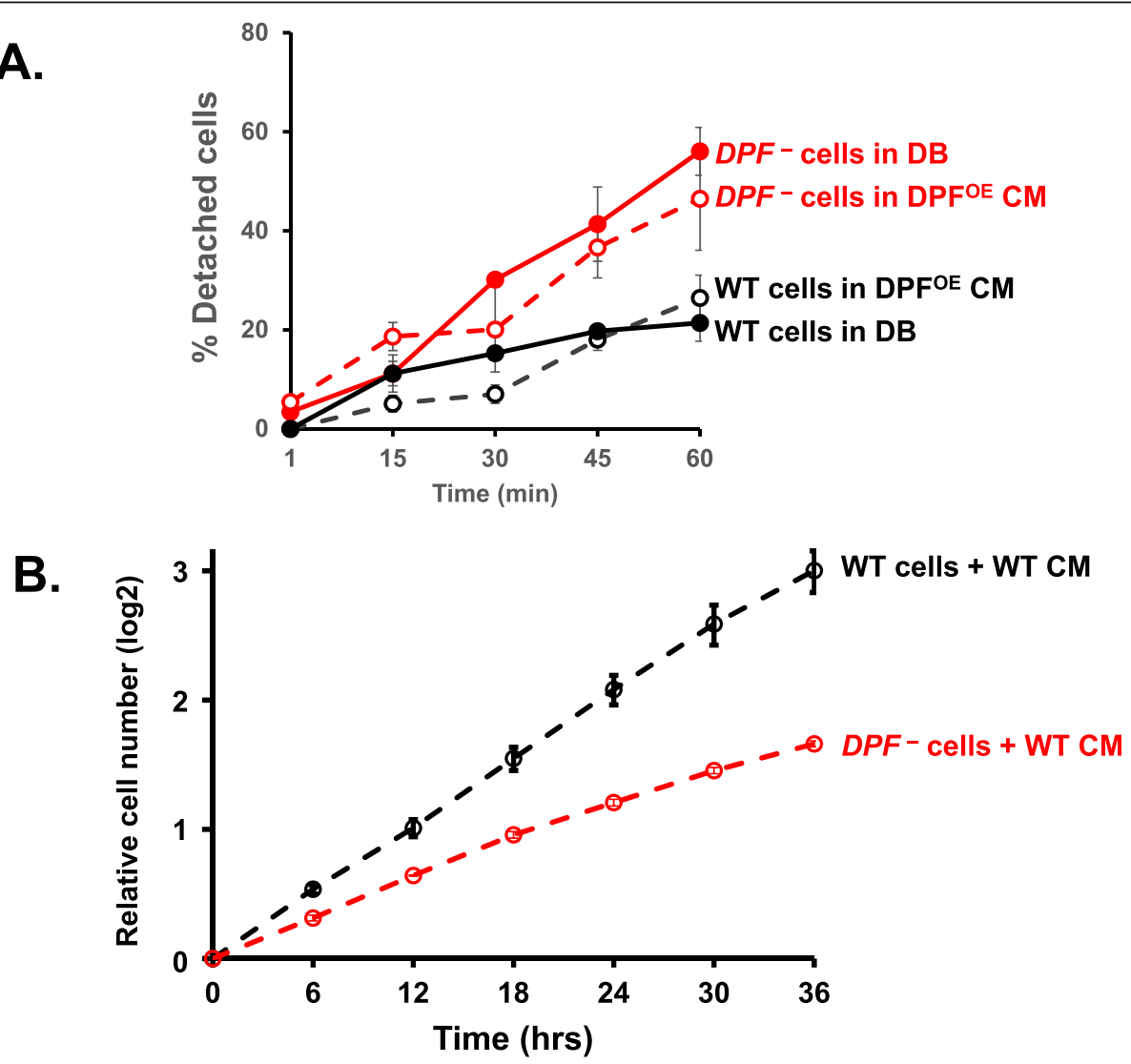

Fig. 10 Cell-autonomous functions of DPF in adhesion and growth. a WT and DPF cells were adhered at a density of $400 \times 10^{3} \mathrm{cells} / \mathrm{cm}^{2}$ to a six-well plate, washed and replenished with fresh, naive DB media or 5-h conditioned media from DPF ${ }^{\mathrm{OE}}$ cells. The dishes were then shaken at indicated time points at $90 \mathrm{rpm}$, and the percentage of de-attached cells quantified. Values indicate Mean \pm SD from triplicate sets and three independent experiments. b Cell growth rates of WT and DPF cells in the presence of fresh growth media that was supplemented with DPFcontaining conditioned growth media from WT cells. Growth rate was monitored at indicated time points. The values represent mean \pm SD from three independent experiments 
functions to promote cell density-dependent development and consequently multi-cell aggregation. Cells at low density do not form aggregates under starvationinduced conditions; however, by increasing extracellular concentrations of DPF, through addition of purified DPF or by overexpression, cells will aggregate at $>4$-fold lower densities than under standard conditions. In parallel, cells lacking DPF require higher cell density than do WT conditions for permissive developmental aggregation. We suggest that an extracellular threshold accumulation of DPF serves as an effective sensing factor to ensure that development proceeds when there are sufficient cell numbers for productive multi-cell formation and differentiation. Above this cell-density threshold, additional DPF would have limited influence. Furthermore, at even higher cell density, DPF is no longer essential for early development or terminal differentiation and fruiting body formation.

DPF is synthesized as a $\sim 160-\mathrm{kDa}$ protein, is inserted into the plasma membrane through an $\mathrm{N}$-terminal signal peptide, and is then anchored by a C-terminal transmembrane domain as a single-pass protein (see Fig. 11). The long $\sim 150-\mathrm{kDa}$ extracellular domain is glycosylated and extracellularly released into the media by proteolytic cleavage and ectodomain shedding. Extracellular DPF then accumulates in proportion to relative cell density to mobilize cells for aggregation.

Unlike the Countin Factor (CF) Complex [30, 31], DPF does not appear to regulate group size. Where increasing concentrations of CF decreases the size of developmental aggregates, WT cells and cells overexpressing DPF form similarly sized aggregates at equivalent cell densities (see Fig. 8a). In addition, where the action of developmental factor CMF is dependent on starvation-induced secretion [36], DPF may be primarily regulated by transcriptional activation. DPF mRNA is rapidly induced at the onset of development [38, 39], and extracellular DPF accumulates at similar rates during both growth and development (see Fig. 4c).

The complexity of the developmental assay read-out (i.e., multi-cell aggregation) for DPF makes it difficult to understand potential DPF ligand interaction or a precise quantitative requirement. Since a 2 -fold dilution of cells is sufficient to prevent aggregation, it is highly unlikely that biochemical responses to DPF occur in a strictly linear manner, but rather at a steep threshold sensing limit (see [2]). We also recognize that DPF cannot be the sole defining factor for cell-density aggregation. While other secreted factors certainly regulate aggregation sensitivity to cell density, our assay conditions more narrowly defined the influencing factors. In addition, regardless of DPF levels, cell-density dilution will reach a nadir below which cell-cell communication becomes ineffective, and distances for migration restrictive.

DPF studies with $g \alpha 9$-null cells [21, 44] may provide certain insight. $\mathrm{G} \alpha 9$ is an inhibitory Go for cAMP receptor 1 (CAR1). Go9 binds to CAR1, and cells deficient in Go9 show increased synthesis of cAMP, faster developmental oscillations in cAMP, and low cell-density aggregation (see Additional file 1: Figure S1C) compared to

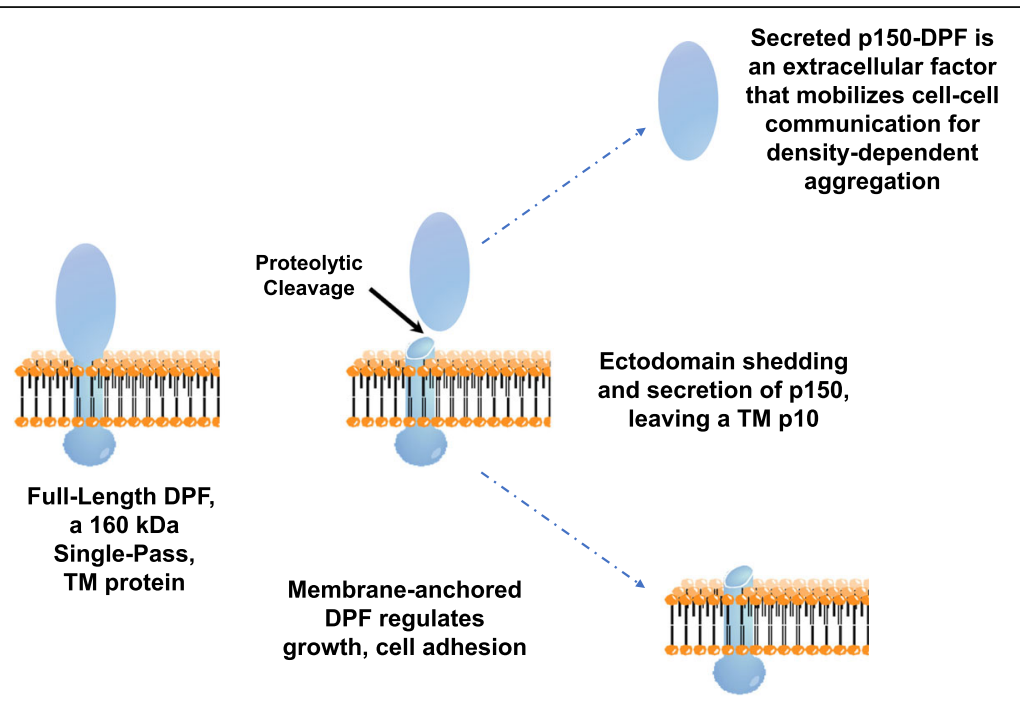

Fig. 11 A model for ectodomain shedding and secretion of DPF. DPF is synthesized as an $\sim 160-k D a$ protein that is inserted into the plasma membrane, following signal peptide cleavage. The transmembrane TM domain near the C-terminus anchors the single-pass DPF in the membrane. The long N-terminal $\sim 150-\mathrm{kDa}$ extracellular domain is glycosylated. Extracellular proteolytic cleavage, $\mathrm{N}$-terminal to the TM domain, releases a p150 fragment into the media; The residual p10 TM/cytoplasmic fragment is retained in the plasma membrane. The secreted p150 possesses density-dependent aggregation activity and at high levels promotes aggregation at sub-optimal cellular densities and defines centers for aggregation. Membrane-anchored DPF has cell-autonomous activity for growth and adhesion 
WT cells [21]. Nonetheless, ga9-null cells are hypersensitive to DPF, aggregating with supplemented DPF at densities $<10$-fold than that of WT (see Additional file 1: Figure S1C), indicating that DPF does not act through G 9 . It is interesting that both $g \alpha 9$-null cells and $\mathrm{DPF}^{\mathrm{OE}}$ cells share another phenotype, suggesting perhaps that DPF may function in converging or parallel pathways.

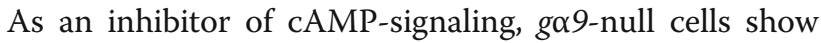
more rapid cAMP-regulated development than WT and, accordingly, define centers that initiate cAMP-signaling when developed in mixed culture with a $>90 \%$ population of WT [21]; $\mathrm{DPF}^{\mathrm{OE}}$ cells similarly show enriched signaling/aggregation center formation in mixed development with WT cells. Furthermore, cells that define aggregation centers are also fated for prespore cytodifferentiation during morphogenetic development $[21,43]$ and both $g \alpha$ 9-null cells and $\mathrm{DPF}^{\mathrm{OE}}$ cells show preferential prespore fate determination when developed in a predominant $99 \%$ WT population. However, our data do not indicate if DPF overexpression promotes the prespore/spore differentiation pathway or is inhibitory toward prestalk/stalk formation.

As in other systems, Dictyostelium utilize multiple extracellular receptor-signaling pathways for potential DPF targeting. GPCRs for several small molecule ligands (e.g., cAMP, folate, ATP) are known [40, 45-47], and secreted proteins $\mathrm{CMF}, \mathrm{CF}$, and chalones are suggested to function through distinct heterotrimeric G proteins [4850]. The TgrB1/TgrC1 proteins represent a different class for cell-cell communication, as a ligand/receptor pair [51]. TgrB1 and TgrC1 are structurally related transmembrane proteins with long extracellular domains. These 2 extracellular domains exhibit physical interaction, with $\mathrm{TgrC} 1$ acting as an extracellular ligand that binds and activates the TgrB1 receptor [52]. Activated TgrB1 signaling is mediated through its Cterminal intracellular cytosolic domain [53]. We also recognize that DPF may facilitate cell-cell contact, in addition to or apart from ligand/receptor-dependent signal transduction, as a developmental priming event. Pathways may involve DPF-DPF homophilic recognitions, either as full-length/full-length DPF interactions and/or as secreted p150/full-length DPF interactions, or heterologous associations.

It is also not clear why centers for cAMP-signaling are enriched for $\mathrm{DPF}^{\mathrm{OE}}$ cells. Secreted DPF may have diffusion limits, and if DPF functions in a path that promotes cAMP-signaling or cAMP persistence cells within an immediate area of highest DPF concentration may exhibit a more rapid and enhanced response for establishing these signaling centers, in contrast to more distal cells, and with possible reflection to morphogen gradients $[7,54,55]$.

Regulation of transmembrane protein function by ectodomain shedding is complex and can release bioactive molecules that act both extra- and intracellularly [56]. Proteolytic cleavage (i.e., shedding) of single pass TM proteins, as for TNF and TGF (in true metazoa) and DPF in Dictyostelium, sheds an activated, extracellular ectodomain, but shedding can also create an alternative TM protein structure that is an available substrate for subsequent intra-membrane cleavage. Although in other systems released cytosolic domains may function as transcription factors, the cytoplasmic domain of DPF is very short $(\sim 30$ amino acids; see Additional file 3: Figure S3C) and we do not see membrane release and cytosolic or nuclear accumulation of tagged-DPF Ctermini. Possibly both the full-length and residual membrane-bound DPF fragments have distinct and specific roles, and certainly DPF exerts cell-autonomous effects that modulate cell adhesion, growth, and perhaps development.

\section{Conclusions}

Dictyostelium grow in the wild as individual cells, but when they become starved for nutrients they are poised to enter a multi-cell developmental program. Multi-cell formation, however, is highly dependent upon cell sufficiency for productive developmental cell-cell communication and aggregation. We have identified the novel protein DPF in Dictyostelium that is secreted by ectodomain shedding and accumulates within the extracellular milieu in parallel with an increasing local cell population. In this manner, DPF serves as a density-sensing factor to correlate the developmental fate switch with the collective local cell population. Regions with the highest DPF concentration preferentially localize at centers for multi-cell formation and additionally determine cell-fate choice. We further demonstrate that DPF also has cell-autonomous functions, most probably associated with the TM/cytoplasmic region. Both segments of DPF, the secreted and the cell-inherent segments, regulate growth and developmental processes.

\section{Methods \\ Cell lines and culture}

Dictyostelium strains [34, 35] were confirmed and were grown axenically in $\mathrm{D} 3 \mathrm{~T}$ medium at $22^{\circ} \mathrm{C}$ in suspension culture [57], at $\sim 180 \mathrm{rpm}$, to a density of $1-1.5 \times 10^{6}$ cells/ml; $D P F$-nulls were maintained and expanded as adhered cells on dishes. ctnA-, CMF-, ga9-, p67-, and $D P F$-null lines (see below) were grown under $10 \mu \mathrm{g} / \mathrm{ml}$ blasticidin selection. DPF overexpressing strains $\left(\mathrm{DPF}^{\mathrm{OE}}\right.$ and $\mathrm{DPF}^{-\mathrm{OE}}$ ) and WT GFP cells were grown with $50 \mu \mathrm{g} /$ $\mathrm{ml} \mathrm{G418.}$

\section{Preparation of conditioned media}

To prepare conditioned media, log phase growing WT, $\mathrm{DPF}^{-}$, and $\mathrm{DPF}^{\mathrm{OE}}$ cells were washed into $\mathrm{DB}$ and 
resuspended at $2 \times 10^{7}$ cells $/ \mathrm{ml}$, at $22^{\circ} \mathrm{C}$ with constant shaking $(180 \mathrm{rpm})$ for $5-18 \mathrm{~h}$. Cell supernatants were passed through the $>30-\mathrm{kDa}$ cut-off filtration system [Centricon (MilliporeSigma)] to concentrate and remove smaller molecules. The concentrates were diluted to the original volume with DB buffer and used in aggregation and developmental assays.

To prepare growth conditioned media, cells were adhered at $10 \%$ confluency in a large petri dish, replenished with a fresh growth media and allowed to grow until $\sim 70 \%$ confluency $(\sim 36 \mathrm{~h})$. Media from growing culture was passed through the $>30-\mathrm{kDa}$ cut-off filtration system, and the concentrates were diluted to the original volume with fresh growth media and used for growth rate studies.

\section{Density-dependent aggregation and development assay} For cell-density aggregation, log-phase growing cells were transferred to developmental buffer (DB) starvation media (10 mM phosphate, $\mathrm{pH} 6.4 ; 2 \mathrm{mM} \mathrm{MgCl}_{2} ; 0.2 \mathrm{mM}$ $\mathrm{CaCl}_{2}$ ) and plated under buffer in microtitre dishes at varying densities, as indicated for each experiment. The plating buffer used was either untreated (naïve) DB, cellconditioned DB (see below) from various cell lines, or varying media extracts at different purification steps, and used at undiluted or diluted strengths using untreated naïve $\mathrm{DB}$.

For relative activity determination assays, cell density was below the threshold level for WT aggregation, generally $\sim 20 \times 10^{3}$ cells $/ \mathrm{cm}^{2}$. Controls with naïve buffer were always performed in parallel, at both aggregation permissive $\left(100 \times 10^{3}\right.$ cells $\left./ \mathrm{cm}^{2}\right)$ and non-permissive $\left(20 \times 10^{3}\right.$ cells $\left./ \mathrm{cm}^{2}\right)$ densities. Relative aggregation was variable, and only semi-quantifiable; 3 separate experiments were performed, with similar result trends. In general, it is calculated as the sum area for cells in aggregates in a well plate compared to that at maximum aggregation, where fewer than $10 \%$ of input cells fail to aggregate.

To analyze development, growing cells in log phase $\left(1-3 \times 10^{6}\right.$ cells $\left./ \mathrm{ml}\right)$ were washed twice in DB buffer and developed on agarose at $400 \times 10^{3} \mathrm{cells} / \mathrm{cm}^{2}$ (or as indicated), and images captured at time intervals $[40,58]$.

\section{Density aggregation factor purification}

Cells were grown to $\log$ phase and transferred to DB buffer. $2000 \mathrm{ml}$ cells were shaken for $18-24 \mathrm{~h}$ at $2 \times 10^{7}$ cells $/ \mathrm{ml}$. Cell-free, $>30-\mathrm{kDa}$ conditioned DB media were prepared by Centricon (MilliporeSigma) $30-\mathrm{kDa}$ filtration, which concentrates to $>10 \times$. Samples from starting preparations were reserved. Purifications were at $4{ }^{\circ} \mathrm{C}$. Samples were adjusted to $1 \mathrm{mM}$ PMSF and loaded onto a Mono Q column and eluted in a linear gradient from $10 \mathrm{mM}$ to $1 \mathrm{M} \mathrm{NaCl}$. Fractions were tested for activity, and the active fractions $(\sim 250 \mathrm{mM} \mathrm{NaCl})$ were pooled and loaded to a phenyl sepharose column in $4 \mathrm{M} \mathrm{NaCl}$ in PB. Fractions were eluted in $250 \mathrm{mM} \mathrm{NH}_{2} \mathrm{SO}_{4}$ decreasing concentration steps from $1 \mathrm{M}$, and the active fractions $\left(\sim 750 \mathrm{mM} \mathrm{NH} \mathrm{NH}_{4}\right)$ adjusted to $10 \mathrm{mM} \mathrm{PB}$ and loaded to wheat germ agglutinin. Bound protein was eluted in $0.5 \mathrm{M}$ glucosamine, dialyzed into $10 \mathrm{mM} \mathrm{PB}$, and loaded for Sepharose 12 fractionation.

Fractions were column adjusted to $\mathrm{PB}$ and tested for density aggregation activity, and the most active fractions used for additional analyses.

\section{SDS gel purification and MS/MS sequencing}

The samples were resolved on a 3-8\% gel, with prior reduction and alkylation, and visualized by silver staining (SilverQuest Silver Staining Kit, Invitrogen). Experimental and control gel bands were excised, de-stained, and washed according to SilverQuest. Proteins were subject to trypsin digestion, peptide extraction, and MS/MS peptide sequencing [59] as a contracted core component of Dr. Michael Kinter, Cleveland Clinic Foundation. Derived peptides were searched by BLAST within dictyBase [34, 35].

p67 peptide sequences match gene name $D D B_{-}$ G0269892 in dictyBase [34, 35] and probably encodes an FAD-Dependent Oxidoreductase; 150 peptide sequences match gene name DDB_G0289949 in dictyBase [34, 35] and encodes DPF, a developmental promoting factor.

\section{Gene constructs}

Full-length coding DPF mRNA is $\sim 4.5 \mathrm{~kb}$. DPF was assembled in several parts by RT-PCR. Each fragment was sequenced, assembled into a single construct and also sequenced. The full-length cDNA was transferred into actin expression vectors [60]. The final assembled cDNA and fusion site for each construct was sequence confirmed.

p67 disruption was by homologous recombination of a blasticidin selection marker into an internal restriction fragment [61]. Gene disruption was determined first by PCR using multiple internal and external primers and confirmed by hybridization and sequencing. DPF-null cells (GWDI_26_C_3) were obtained and confirmed from GWDI (https://remi-seq.org) bank in dictyBase $[34,35]$; disruption was within exon 2 , at amino acid position 200, within the secreted extracellular domain.

\section{Immunoblotting}

Whole cell lysates were prepared in Laemmli lysis buffer with $2.5 \%$ of $\beta$-mercaptoethanol and incubated at $95^{\circ} \mathrm{C}$ for $10 \mathrm{~min}$. Cell lysates were immunoblotted following gel electrophoresis (Bio-Rad, 4-20\% tris glycine gels) with antibodies to DPF, FLAG (F3165, Sigma), GFP [57], CAR1 [62], Discoidin 1 (A. Kuspa, Baylor Medical College), and actin proteins. For CAR1 proteins, cell lysates 
were not heated. DPF antibody was mouse polyclonal, prepared (Genewiz) to a single peptide (see Additional file 3: Figure S3C).

\section{a-FLAG affinity purification}

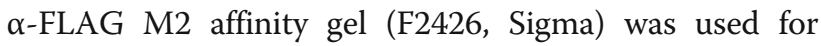
binding, following the manufacturer's instructions. Elution was for $1 \mathrm{~h}$ with FLAG peptide (F4799, Sigma) at $0.5 \mathrm{mg} / \mathrm{ml}$ and $1: 1$ bead volume ratio.

\section{RNA extraction and hybridization blotting}

Total RNA was isolated using the Qiagen RNAeasy mini preparation kit [Qiagen \# 74104] and following the manufacturer's protocol. RNAs of equal quantity were separated on a $1.2 \%$ agarose- $6 \%$ formaldehyde gels, blotted onto nylon membranes, and hybridized with cDNA probe labeled with $\left[\alpha-{ }^{32} \mathrm{P}\right] \mathrm{dCTP}[63]$.

\section{Chemotaxis}

Growing WT and $\mathrm{DPF}^{\mathrm{OE}}$ cells were transferred to 10 $\mathrm{mM}$ phosphate buffer, $\mathrm{pH} 6.5$. Sixty microliters $(\sim 1 \times$ $10^{3}$ cells) was added to the upper well of a chemotaxis plate (Essen Bioscience; cat \# 4582200). Two hundred microliters of $\mathrm{PB}$, with or without cAMP as indicated, was added to the bottom well, and the plate was transferred to the IncuCyte chamber, at $22^{\circ} \mathrm{C}[35,36]$. Chemotaxis was recorded over time as a function of the cells imaged at the under surface of the membrane, using a $\times 10$ objective lens; data were exported, analyzed, and graphed using Microsoft Excel [40, 41].

\section{GFP cell fluorescence}

C-GFP DPF cells were shaken in DB and washed into phosphate buffer. Cells were plated on a glass bottom dishes (MatTek Corporation) and observed using the Axiovert $100 \mathrm{M}$ (Carl Zeiss) inverted microscope [64].

\section{Membrane preparations}

Cell suspensions at $8 \times 10^{7}$ cells $/ \mathrm{ml}$ in $10 \mathrm{~mm}$ Tris- $\mathrm{HCl}$ (pH 8), $1 \mathrm{~mm} \mathrm{MgSO}_{4}, 0.2 \mathrm{~mm}$ EGTA, and 10\% glycerol were lysed by passage through a $5-\mu \mathrm{m}$ nucleopore filter. Lysates were centrifuged at $4{ }^{\circ} \mathrm{C}$ for $30 \mathrm{~min}$ [65].

\section{Cell-matrix surface adhesion assay}

Cell adhesion assays were performed as described by [64] with slight modification. Log-phase growing cells were adhered at a density of $400 \times 10^{3}$ cells $/ \mathrm{cm}^{2}$ in a sixwell plate, washed, and replenished with $\mathrm{DB}$ or conditioned DB media. The dishes were then shaken at indicated time points at $90 \mathrm{rpm}$, and the percent of deattached cells quantified [Cellometer Vision-Nexcelom Bioscience].

\section{Cell growth rates assay}

To measure the cell growth rates, we adhered $5 \times 10^{3}$ cells/well in a 12-well plate, replenished with fresh growth media with or without DPF and incubated at $22^{\circ} \mathrm{C}$. Growth kinetics were monitored in an Incucyte chamber, imaged using $\times 10$ objective lens; data were exported, analyzed, and graphed using Microsoft Excel.

\section{Cell volume quantification}

We measured packed cell volume as a relative estimate of comparative cell size. WT, $\mathrm{DPF}^{-}, \mathrm{DPF}^{\mathrm{OE}}$, and $\mathrm{DPF}^{-\mathrm{OE}}$ cells were grown in a dish culture until $70 \%$ confluency. Cells were collected in fresh media and diluted to a density of $5 \times 10^{6}$ cells $/ \mathrm{ml}$. One milliliter of cell suspension was transferred to the Packed Cell Volume tubes (catalog \# TPP-87005), spun at 3000 RPM for $1 \mathrm{~min}$. The graduated scale on PCV tubes estimates the relative changes in cell volume.

\section{Supplementary information}

Supplementary information accompanies this paper at https://doi.org/10. 1186/s12915-019-0714-9.

Additional file 1: Figure S1. Conditioned media promotes aggregation at low cell density. A. Log-phase growing WT Dictyostelium were plated under DB starvation buffer at indicated cell densities for $24 \mathrm{hrs}$, using fresh, naïve DB media. Each immaged mass at $50 \times 10^{3}$ cells $/ \mathrm{cm}^{2}$ represents an individual cell aggregate grouping, not an individual cell. No aggregates are seen at $25 \times 10^{3}$ cells $/ \mathrm{cm}^{2}$. Distinction between single and aggregated cells is more easily seen in $3.5 x$-enlarged figures below, with aggregation efficiencies indicated. B. Log-phase growing WT Dictyostelium were plated under DB starvation buffer at indicated cell densities for 24 hrs, using either fresh, naïve DB media or cell-free, $>30$ kDa conditioned media from WT cells starved in DB for 18 hrs, with aggregation efficiencies indicated. Scale bar $=200 \mu \mathrm{m}$. C. Log-phase ga9-null cells were plated under DB starvation buffer at indicated cell densities for 24 hrs, using either fresh, naïve DB media or cell-free, $>30$ kDa conditioned media from WT cells starved in DB for $18 \mathrm{~h}$.

Additional file 2: Figure S2. Column purifications for density aggregation activity. Mono Q and phenyl sepharose fractionations of conditioned media from WT for density-dependent aggregation activity (see Fig. 2a). Protein profiles are indicated, with relative salt concentration elutions.

Additional file 3: Figure S3. Peptide sequence matching. Peptide sequences from Fig. 2a,b,c were compared to all Dictyostelium proteins. Shown are deduced proteins for (A) PDE1, (B) p67 (an FAD-dependent oxidoreductase), and (C) DPF (Development Promoting Factor). Amino acid color symbols are indicated.

Additional file 4: Figure S4. Log-phase growing WT cells were plated under DB starvation buffer at $20 \times 10^{3}$ cells $/ \mathrm{cm}^{2}$ with fresh, naïve DB media or cell-free, $>30 \mathrm{kDa}$ conditioned media from the indicated cell lines starved in DB for $18 \mathrm{~h}$.

Additional file 5: Figure S5. Left: A 1:99 mixed population of WT GFP or DPF ${ }^{\mathrm{OE}}$ cells plated for development to the slug stage. Right: A 100\% population of C-GFPOE cells plated for development to terminal differentiation. Shown are confocal images including both DIC and GFP fluorescence, with prespore/prestalk and spore/stalk regions indicated.

Additional file 6: Figure S6. DPF is required for density-dependent aggregation but not terminal differentiation. A. Log-phase growing WT and DPF-nulls cells were placed on DB starvation buffer agar plates at varying cell densities and aggregation visually monitored at $8 \mathrm{hr}$. B. Log-phase growing WT and DPF-nulls cells were placed on DB starvation buffer agar 
plates at $200 \times 10^{3}$ cells $/ \mathrm{cm}^{2}$ and aggregation visually monitored at $5 \mathrm{hr}$. C. Log-phase growing WT and DPF ${ }^{\mathrm{OE}}$ cells were placed on DB starvation buffer agar plates at $50 \times 10^{3} \mathrm{cells} / \mathrm{cm}^{2}$ and aggregation visually monitored at $5 \mathrm{hr}$. D. WT and DPF-null cells were developed on DB agar for 24 hr. Images at comparable magnification show terminal fruiting body formation, with similar stalk/sorus size ratios.

Additional file 7: Figure S7. Growth rates and cell volume of WT and DPF cells. A. Cell growth rates of WT, DPF ${ }^{\mathrm{OE}}$, and DPF and DPF ${ }^{-\mathrm{OE}}$ cells monitored at indicated time points. The values represent mean \pm SD from three independent experiments. B. The relative packed cell volume of log-phase growing WT, DPF, DPF ${ }^{\mathrm{OE}}$, DPF ${ }^{\mathrm{OE}}$ cells in growth media. The relative cell volume was measured using Packed Cell Volume (PCV) tubes and presented as percentage relative to WT cells. Data from three independent experiments are shown for each.

Additional file 8: Movie S1. A 9:1 mixed population of WT and CGFPOE cells were plated for development and followed over time (see Fig. 8b).

\section{Acknowledgements}

We thank Drs. R. Gomer, R. Kessin, R.A. Firtel, P. Fey, J. Platt, A. Majithia, D. Rosel, V. McMains, A. Kuspa, and other colleagues for cell lines, etc., and/or discussion during the course of the study, and, especially, dictyBase (http:// dictybase.org/). Finally, we thank Drs. A. Kuspa and C. Dinh for providing aDiscoidin 1 and assistance in detection of Discoidin 1.

\section{Authors' contributions}

The original work was conceived by JB and ARK and then extended by NPM PJ, and F-SC. Major experiments were done by NPM, PJ, and JB. F-SC provided additional essential analytic data. NPM, PJ, JB, F-SC, and ARK analyzed all the data and discussed research directions. JB and ARK wrote an initial draft. ARK revised, and NPM, PJ, F-SC, JB, and ARK edited continuously and contributed to and approved the final version. We confirm that all authors read and approved the final manuscript.

\section{Funding}

This work was supported by the Intramural Research Program of the National Institute of Diabetes and Digestive and Kidney Diseases, National Institutes of Health.

\section{Availability of data and materials}

Cell lines and vectors are available or accessed at dictyBase (http://dictybase. org). Most notably, DPF is DDB_G0289949 [34, 35], and the DPF-null cell line is mutant GWDI_26_C_3 $[34,35]$; GWDI mutants can be requested through the stock center (http://dictybase.org/StockCenter/StockCenter.html) within dictyBase.

\section{Ethics approval and consent to participate}

No animal research; not applicable.

\section{Consent for publication}

No human subjects; not applicable.

\section{Competing interests}

The authors declare that they have no competing interests.

\section{Author details \\ 'Laboratory of Cellular and Developmental Biology, National Institute of Diabetes and Digestive and Kidney Diseases, The National Institutes of Health, Bethesda, MD 20892, USA. ² Laboratory of Immunogenetics Twinbrook Imaging Facility, National Institute of Allergy and Infectious Diseases, The National Institutes of Health, Rockville, MD 20852, USA.}

Received: 1 May 2019 Accepted: 24 October 2019

Published online: 02 December 2019

\section{References}

1. Abisado RG, Benomar S, Klaus JR, Dandekar AA, Chandler JR. Bacterial quorum sensing and microbial community interactions. mBio. 2018;9(3): e02331-17.
2. Polonsky M, Rimer J, Kern-Perets A, Zaretsky I, Miller S, Bornstein C, David E, Kopelman NM, Stelzer G, Porat Z, et al. Induction of CD4 T cell memory by local cellular collectivity. Science. 2018;360(6394):eaaj1853.

3. Watt Kl, Harvey KF, Gregorevic P. Regulation of tissue growth by the mammalian hippo signaling pathway. Front Physiol. 2017;8:942.

4. Sagner A, Briscoe J. Morphogen interpretation: concentration, time, competence, and signaling dynamics. Wiley Interdiscip Rev Dev Biol. 2017;6(4):e271.

5. Eder D, Aegerter C, Basler K. Forces controlling organ growth and size. Mech Dev. 2017;144(Pt A):53-61

6. Amourda C, Saunders TE. Gene expression boundary scaling and organ size regulation in the Drosophila embryo. Develop Growth Differ. 2017;59(1):21-32.

7. Shilo BZ, Barkai N. Buffering global variability of morphogen gradients. Dev Cell. 2017:40(5):429-38.

8. Shilo BZ, Haskel-Ittah M, Ben-Zvi D, Schejter ED, Barkai N. Creating gradients by morphogen shuttling. Trends Genet. 2013;29(6):339-47.

9. Du Q, Kawabe Y, Schilde C, Chen ZH, Schaap P. The evolution of aggregative multicellularity and cell-cell communication in the Dictyostelia. J Mol Biol. 2015;427(23):3722-33.

10. McMains VC, Liao XH, Kimmel AR. Oscillatory signaling and network responses during the development of Dictyostelium discoideum. Ageing Res Rev. 2008;7(3):234-48.

11. Loomis WF. Genetic control of morphogenesis in Dictyostelium. Dev Biol. 2015:402(2):146-61.

12. Gomer RH, Jang W, Brazill D. Cell density sensing and size determination. Develop Growth Differ. 2011:53(4):482-94.

13. Konijn TM, Raper KB. Cell aggregation in Dictyostelium discoideum. Dev Biol. 1961;3:725-56.

14. Hashimoto Y, Cohen MH, Robertson A. Cell density dependence of the aggregation characteristics of the cellular slime mould Dictyostelium discoideum. J Cell Sci. 1975;19(1):215-29.

15. Gingle AR. Critical density for relaying in Dictyostelium discoideum and its relation to phosphodiesterase secretion into the extracellular medium. J Cell Sci. 1976;20(1):1-20.

16. Cohen $\mathrm{MH}$, Robertson $\mathrm{A}$. Chemotaxis and the early stages of aggregation in cellular slime molds. J Theor Biol. 1971;31(1):119-30.

17. Devreotes $P$, Horwitz AR. Signaling networks that regulate cell migration. Cold Spring Harb Perspect Biol. 2015;7(8):a005959.

18. Ohta Y, Furuta T, Nagai T, Horikawa K. Red fluorescent CAMP indicator with increased affinity and expanded dynamic range. Sci Rep. 2018;8(1):1866.

19. Gregor T, Fujimoto K, Masaki N, Sawai S. The onset of collective behavior in social amoebae. Science. 2010;328(5981):1021-5.

20. Palsson E, Lee KJ, Goldstein RE, Franke J, Kessin RH, Cox EC. Selection for spiral waves in the social amoebae Dictyostelium. Proc Natl Acad Sci U S A. 1997;94(25):13719-23.

21. Brzostowski JA, Johnson C, Kimmel AR. Galpha-mediated inhibition of developmental signal response. Curr Biol. 2002;12(14):1199-208.

22. Tang $Y$, Gomer RH. A protein with similarity to PTEN regulates aggregation territory size by decreasing cyclic AMP pulse size during Dictyostelium discoideum development. Eukaryot Cell. 2008;7(10):1758-70.

23. Brzostowski JA, Sawai S, Rozov O, Liao XH, Imoto D, Parent CA, Kimmel AR. Phosphorylation of chemoattractant receptors regulates chemotaxis, actin reorganization and signal relay. J Cell Sci. 2013;126(Pt 20):4614-26.

24. Brock DA, Gomer RH. A secreted factor represses cell proliferation in Dictyostelium. Development. 2005;132(20):4553-62.

25. Bakthavatsalam D, Brock DA, Nikravan NN, Houston KD, Hatton RD, Gomer $\mathrm{RH}$. The secreted Dictyostelium protein CfaD is a chalone. J Cell Sci. 2008; 121(Pt 15):2473-80.

26. Yarger J, Soll DR. Transcription and division inhibitors in the medium of stationary phase cultures of the slime mold Dictyostelium discoideum. Biochim Biophys Acta. 1975;390(1):45-55.

27. Rathi A, Kayman SC, Clarke M. Induction of gene expression in Dictyostelium by prestarvation factor, a factor secreted by growing cells. Dev Genet. 1991;12(1-2):82-7.

28. Clarke M, Gomer RH. PSF and CMF, autocrine factors that regulate gene expression during growth and early development of Dictyostelium. Experientia. 1995:51(12):1124-34.

29. Brock DA, Gomer RH. A cell-counting factor regulating structure size in Dictyostelium. Genes Dev. 1999:13(15):1960-9.

30. Brock DA, Hatton RD, Giurgiutiu DV, Scott B, Jang W, Ammann R, Gomer RH CF45-1, a secreted protein which participates in Dictyostelium group size regulation. Eukaryot Cell. 2003;2(4):788-97. 
31. Brock DA, van Egmond WN, Shamoo Y, Hatton RD, Gomer RH. A 60kilodalton protein component of the counting factor complex regulates group size in Dictyostelium discoideum. Eukaryot Cell. 2006;5(9):1532-8.

32. Gomer RH, Yuen IS, Firtel RA. A secreted $80 \times 10(3)$ Mr protein mediates sensing of cell density and the onset of development in Dictyostelium. Development. 1991;112(1):269-78.

33. Bakthavatsalam D, Gomer RH. The secreted proteome profile of developing Dictyostelium discoideum cells. Proteomics. 2010;10(13):2556-9.

34. Fey P, Dodson RJ, Basu S, Chisholm RL. One stop shop for everything Dictyostelium: dictyBase and the Dicty Stock Center in 2012. Methods Mol Biol. 2013;983:59-92.

35. Basu S, Fey P, Pandit Y, Dodson R, Kibbe WA, Chisholm RL. DictyBase 2013 : integrating multiple Dictyostelid species. Nucleic Acids Res. 2013; 41(Database issue):D676-83.

36. Yuen IS, Taphouse C, Halfant KA, Gomer RH. Regulation and processing of a secreted protein that mediates sensing of cell density in Dictyostelium. Development. 1991;113(4):1375-85.

37. Kolbinger A, Gao T, Brock D, Ammann R, Kisters A, Kellermann J, Hatton D, Gomer RH, Wetterauer B. A cysteine-rich extracellular protein containing a PA14 domain mediates quorum sensing in Dictyostelium discoideum. Eukaryot Cell. 2005;4(6):991-8.

38. Parikh A, Miranda ER, Katoh-Kurasawa M, Fuller D, Rot G, Zagar L, Curk T, Sucgang R, Chen R, Zupan B, et al. Conserved developmental transcriptomes in evolutionarily divergent species. Genome Biol. 2010;11(3): R35.

39. Rosengarten RD, Santhanam B, Fuller D, Katoh-Kurasawa M, Loomis WF, Zupan B, Shaulsky G. Leaps and lulls in the developmental transcriptome of Dictyostelium discoideum. BMC Genomics. 2015;16:294

40. Meena NP, Kimmel AR. Chemotactic network responses to live bacteria show independence of phagocytosis from chemoreceptor sensing. Elife. 2017;6:e24627

41. Meena NP, Kimmel AR. Quantification of live bacterial sensing for chemotaxis and phagocytosis and of macropinocytosis. Front Cell Infect Microbiol. 2018:8:62

42. Thompson CR, Reichelt S, Kay RR. A demonstration of pattern formation without positional information in Dictyostelium. Develop Growth Differ. 2004;46(4):363-9.

43. Huang HJ, Takagawa D, Weeks G, Pears C. Cells at the center of Dictyostelium aggregates become spores. Dev Biol. 1997;192(2):564-71.

44. Brzostowski JA, Parent CA, Kimmel AR. A G alpha-dependent pathway that antagonizes multiple chemoattractant responses that regulate directional cell movement. Genes Dev. 2004;18(7):805-15.

45. Pan $M, X u X$, Chen $Y$, Jin T. Identification of a chemoattractant G-proteincoupled receptor for folic acid that controls both chemotaxis and phagocytosis. Dev Cell. 2016;36(4):428-39.

46. Saxe CL 3rd, Johnson RL, Devreotes PN, Kimmel AR. Expression of a CAMP receptor gene of Dictyostelium and evidence for a multigene family. Genes Dev. 1991;5(1):1-8

47. Baines A, Parkinson K, Sim JA, Bragg L, Thompson CR, North RA. Functional properties of five Dictyostelium discoideum P2X receptors. J Biol Chem. 2013;288(29):20992-1000.

48. Tang L, Ammann R, Gao T, Gomer RH. A cell number-counting factor regulates group size in Dictyostelium by differentially modulating CAMPinduced CAMP and CGMP pulse sizes. J Biol Chem. 2001;276(29):27663-9.

49. Brazill DT, Lindsey DF, Bishop JD, Gomer RH. Cell density sensing mediated by a $\mathrm{G}$ protein-coupled receptor activating phospholipase C. J Biol Chem. 1998;273(14):8161-8.

50. Bakthavatsalam D, Choe JM, Hanson NE, Gomer RH. A Dictyostelium chalone uses G proteins to regulate proliferation. BMC Biol. 2009;7:44.

51. Hirose S, Benabentos R, Ho HI, Kuspa A, Shaulsky G. Self-recognition in social amoebae is mediated by allelic pairs of tiger genes. Science. 2011; 333(6041):467-70.

52. Hirose S, Santhanam B, Katoh-Kurosawa M, Shaulsky G, Kuspa A. Allorecognition, via TgrB1 and TgrC1, mediates the transition from unicellularity to multicellularity in the social amoeba Dictyostelium discoideum. Development. 2015;142(20):3561-70.

53. Hirose S, Chen G, Kuspa A, Shaulsky G. The polymorphic proteins TgrB1 and TgrC1 function as a ligand-receptor pair in Dictyostelium allorecognition. J Cell Sci. 2017;130(23):4002-12.

54. Wolpert L. Positional information and pattern formation. Curr Top Dev Biol. 2016;117:597-608.
55. Briscoe J, Small S. Morphogen rules: design principles of gradient-mediated embryo patterning. Development. 2015;142(23):3996-4009.

56. Lichtenthaler SF, Lemberg MK, Fluhrer R. Proteolytic ectodomain shedding of membrane proteins in mammals-hardware, concepts, and recent developments. EMBO J. 2018;37(15):e99456.

57. Meena NP, Kimmel AR. Biochemical responses to chemically distinct chemoattractants during the growth and development of Dictyostelium. Methods Mol Biol. 2016;1407:141-51.

58. Platt JL, Rogers BJ, Rogers KC, Harwood AJ, Kimmel AR. Different CHD chromatin remodelers are required for expression of distinct gene sets and specific stages during development of Dictyostelium discoideum. Development. 2013;140(24):4926-36.

59. Ziady AG, Kinter M. Protein sequencing with tandem mass spectrometry. Methods Mol Biol. 2009;544:325-41.

60. Dubin M, Nellen W. A versatile set of tagged expression vectors to monitor protein localisation and function in Dictyostelium. Gene. 2010;465(1-2):1-8.

61. Kimmel AR, Faix J. Generation of multiple knockout mutants using the CreloxP system. Methods Mol Biol. 2006;346:187-99.

62. Hereld D, Vaughan R, Kim JY, Borleis J, Devreotes P. Localization of ligandinduced phosphorylation sites to serine clusters in the C-terminal domain of the Dictyostelium CAMP receptor, CAR1. J Biol Chem. 1994;269(9):7036-44.

63. Rosel D, Kimmel AR. The COP9 signalosome regulates cell proliferation of Dictyostelium discoideum. Eur J Cell Biol. 2006;85(9-10):1023-34.

64. Khurana T, Brzostowski JA, Kimmel AR. A Rab21/LIM-only/CH-LIM complex regulates phagocytosis via both activating and inhibitory mechanisms. EMBO J. 2005:24(13):2254-64.

65. Chen MY, Long Y, Devreotes PN. A novel cytosolic regulator, pianissimo, is required for chemoattractant receptor and $\mathrm{G}$ protein-mediated activation of the 12 transmembrane domain adenylyl cyclase in Dictyostelium. Genes Dev. 1997;11(23):3218-31.

\section{Publisher's Note}

Springer Nature remains neutral with regard to jurisdictional claims in published maps and institutional affiliations.

Ready to submit your research? Choose BMC and benefit from:

- fast, convenient online submission

- thorough peer review by experienced researchers in your field

- rapid publication on acceptance

- support for research data, including large and complex data types

- gold Open Access which fosters wider collaboration and increased citations

- maximum visibility for your research: over $100 \mathrm{M}$ website views per year

At BMC, research is always in progress.

Learn more biomedcentral.com/submissions 